\title{
Articles
}

\section{Confronting the Peppercorn Settlement in Merger Litigation: An Empirical Analysis and a Proposal for Reform}

\author{
Jill E. Fisch, ${ }^{*}$ Sean J. Griffith ${ }^{* *} \&$ Steven Davidoff \\ Solomon
}

Shareholder litigation challenging corporate mergers is ubiquitous, with the likelihood of a shareholder suit exceeding $90 \%$. The value of this litigation, however, is questionable. The vast majority of merger cases settle for nothing more than supplemental disclosures in the merger proxy statement. The attorneys that bring these lawsuits are compensated for their efforts with a court-awarded fee. This leads critics to charge that merger litigation benefits only the lawyers who bring the claims, not the shareholders they represent. In response, defenders of merger litigation argue that the lawsuits serve a useful oversight function and that the improved disclosures that result are beneficial to shareholders.

This Article offers a new approach to assessing the value of these claims by empirically testing the relationship between merger litigation and shareholder voting on the merger. If the supplemental disclosures produced by the settlement of merger litigation are valuable, they should affect shareholder voting behavior. Specifically, supplemental disclosures that are, in effect, "compelled" by settlement should produce new and unfavorable information about the merger and lead to a lower percentage of shares voted in favor of it. Applying this hypothesis to a hand-collected sample of 453 large public

* Perry Golkin Professor of Law; Co-Director, Institute for Law \& Economics, University of Pennsylvania Law School.

** T.J. Maloney Professor of Law; Director, Corporate Law Center, Fordham University School of Law.

****Professor of Law, University of California, Berkeley School of Law. Thanks to Randy Baron, Bill Carney, Michael Chepiga, Adam Emmerich, Travis Laster, Mark Lebovitch, Mitchell Lowenthal, Robert Reder, Bill Savitt, Charles Schwartz, Leo Strine, Steve Thel, Bill Wang, and Daniel Wolf for comments on earlier drafts. We are also grateful for comments we received at workshop presentations at the University of Pennsylvania Law School; University of California, Berkeley, School of Law; the Workshop for Corporate \& Securities Litigation sponsored by the University of Illinois College of Law and the University of Richmond School of Law; Fordham Law School; and the Federalist Society's Sixteenth Annual Faculty Conference. Thanks to Jon Allan, Russell Gray, Scott Prince, and Meghan Ferrer for superlative research assistance. The viewpoints and any errors expressed herein are the authors' alone. 
company mergers from 2005 to 2012, we find no such effect. We find no significant evidence that disclosure-only settlements affect shareholder voting.

These findings warrant a reconsideration of Delaware merger law. Specifically, under current law, supplemental disclosures are viewed by courts as providing a substantial benefit to the shareholder class. In turn, this substantial benefit entitles the plaintiffs' lawyers to an award of attorneys' fees. Our evidence suggests that this legal analysis is misguided and that supplemental disclosures do not in fact constitute a substantial benefit. As a result, and in light of the substantial costs generated by public-company merger litigation, we argue that courts should reject disclosure settlements as a basis for attorneys' fee awards.

Our approach responds to critiques of merger litigation as excessive and frivolous by reducing the incentive for plaintiffs' lawyers to bring weak cases, but it would have an additional benefit. Current practice drags state court judges into the task of indirectly promulgating disclosure standards in connection with the approval of fee awards. We argue, instead, for a more efficient specialization between state and federal courts in the regulation of mergers: public company merger disclosure should be policed by the federal securities laws while state corporate law focuses on substantive fairness.

It is a fact evident to all of those who are familiar with shareholder litigation that surviving a motion to dismiss means, as a practical matter, that economical rational defendants... will settle such claims, often for a peppercorn and a fee. ${ }^{1}$

-Chancellor William T. Allen in Solomon v. Pathe

\section{Introduction}

Deal litigation is pervasive in the United States. Multiple teams of plaintiffs file lawsuits challenging virtually every public company merger, ${ }^{2}$ often in multiple jurisdictions. ${ }^{3}$ Moreover, the frequency of merger litigation has risen sharply over the last several years. ${ }^{4}$ In $2012,93 \%$ of

1. Solomon v. Pathe Commc'ns Corp., No. CIV. A. 12563, 1995 WL 250374, at*4 (Del. Ch. Apr. 21, 1995) (footnote omitted).

2. Both our empirical analysis and the policy proposals in this Article are limited to mergers that involve publicly traded target companies. We do not address the role of litigation in policing mergers involving private companies.

3. See infra note 214 and accompanying text.

4. See Matthew D. Cain \& Steven Davidoff Solomon, A Great Game: The Dynamics of State Competition and Litigation, 100 IOWA L. REV. 465, 469 (2015) (reporting that although only $39.3 \%$ of transactions incurred litigation in 2005 , the frequency of litigation had risen to $92.1 \%$ by 2011). 
deals over $\$ 100$ million and $96 \%$ of deals over $\$ 500$ million were challenged in shareholder litigation. ${ }^{5}$ In 2013, the frequency was even higher $-97.5 \%$ of deals over $\$ 100$ million were challenged through litigation, and each transaction triggered an average of seven separate lawsuits. ${ }^{6}$

Although deal litigation is pervasive, these lawsuits rarely result in a monetary recovery for the plaintiff class. Rather, the vast majority end in settlement or dismissal. In most settled cases, the only relief provided to shareholders consists of supplemental disclosures in the merger proxy statement. ${ }^{7} \quad$ In compensation for the benefit produced by these settlements - often worth no more, in the words of a famous jurist, than a "peppercorn"-plaintiffs' attorneys receive a fee award. ${ }^{8}$

The dynamic, in which every deal is challenged but only the lawyers get paid, has led to widespread skepticism concerning the value of public company merger litigation among both academic and professional commentators. ${ }^{9}$ The view underlying much of this skepticism is that litigation

5. Robert M. Daines \& Olga Koumrian, Cornerstone Research, Shareholder LITIGATION INVOLVING MERGERS AND ACQUISITIONS 1 \& fig.1 (2013), available at http://cornerstone.com/Publications/Reports/Shareholder-Litigation-Involving-Mergers-andAcqui, archived at http://perma.cc/TRL8-QNTK?type=pdf; see also Matthew D. Cain \& Steven M. Davidoff, Takeover Litigation in 2012, at 1-2 \& tbl.A (Feb. 1, 2013) (unpublished manuscript), available at http://ssm.com/abstract $=2216727$, archived at http://perma.cc/X8HDPLHC (finding approximately $92 \%$ of deals over $\$ 100$ million resulted in merger litigation in 2012).

6. Matthew D. Cain \& Steven M. Davidoff, Takeover Litigation in 2013, at 1-2 \& tbl.A (Moritz Coll. of Law Ctr. for Interdisciplinary Law \& Policy Studies, Public Law \& Legal Theory Working Paper Series No. 236, 2014), available at http://ssrn.com/abstract=2377001, archived at http://perma.cc/XP2B-8C8B.

7. See DAINES \& KOUMRIAN, supra note 5, at 6 fig.7 (finding that shareholders received only supplemental disclosures in $75 \%-88 \%$ of settlements between 2009 to 2012); Cain \& Davidoff, supra note 5 , at 4 (finding that disclosure-only settlements accounted for over $80 \%$ of all settlements in 2012); Ann Woolner et al., When Merger Suits Enrich Only Lawyers, BLOOMBERG (Feb. 16, 2012, 12:59 PM), http://www.bloomberg.com/news/2012-02-16/lawyers-cash-in-whileinvestor-clients-get-nothing-in-merger-lawsuit-deals.html, archived at http://perma.cc/32HYA22M (reporting that 70\% of merger lawsuits in Delaware during 2010 and 2011 made money for plaintiffs' attorneys but not their clients). The supplemental disclosure may be a part of the target company's proxy statement or prospectus or, in some cases, the target's Schedule 14D-9. For brevity, we will refer to all of these collectively as the "proxy."

8. Solomon v. Pathe Commc'ns Corp., No. CIV. A. 12563, 1995 WL 250374, at *4 (Del. Ch. Apr. 21, 1995).

9. See, e.g., Joel C. HaIms \& JAmes J. BEHA, II, RECENT Decisions Show Courts Closely SCRUTINIZING Fee AWARdS IN M\&A Litigation SETTLEMENTS 1 (2013) (noting that shareholder suits follow virtually every major merger announcement and the payment of attomeys' fees has essentially become a tax on significant mergers and acquisitions), available at http://www.mofo.com/files/Uploads/Images/130418-In-the-courts.pdf, archived at http://perma.cc 19NBW-VL2S; Phillip R. Sumpter, Adjusting Attorneys' Fee Awards: The Delaware Court of Chancery's Answer to Incentivizing Meritorious Disclosure-Only Settlements, 15 U. PA. J. Bus. L. 669, 688-91 (2013) (describing four types of criticism the Chancery Court has expressed); David 
that returns no monetary recovery to the plaintiff class must be without merit. $^{10}$ Equating merit and monetary recovery, however, implicitly dismisses the value of nonpecuniary relief. Such nonpecuniary relief may be valuable to shareholders, but it is hard to determine its value.

Importantly, Delaware law explicitly recognizes the potential value of nonpecuniary relief in its litigation incentive structure. Delaware courts award legal fees to plaintiffs' attorneys on the basis of lawsuits that provide nonpecuniary relief to the plaintiff class as long as that relief constitutes a corporate benefit. ${ }^{11}$ Nevertheless, Delaware courts recognize that the value of nonpecuniary benefits is difficult to quantify. Courts refer to the value of amendments and supplemental disclosures as "qualitative" and "intangible," meaning, essentially, that they cannot be measured. ${ }^{12}$ Without a metric for the value of nonpecuniary relief, it is difficult to determine the utility of the litigation and, in particular, to determine the extent to which courts, by awarding fees, should encourage the pursuit of litigation that tends to result in nonpecuniary settlements. ${ }^{13}$

In this Article, we offer a way out of the impasse. We propose that the value of nonpecuniary relief in merger settlements be measured by its effect on shareholder voting. Because nonpecuniary relief takes three basic forms in the context of merger litigation--settlements that amend the terms of the merger (amendment settlements); settlements that provide only supplemental disclosures (disclosure-only settlements); and settlements which provide for an increase in the merger consideration (consideration-increase settlements) - we separate each and test their effect on how shareholders

H. Webber, Private Policing of Mergers and Acquisitions: An Empirical Assessment of Institutional Lead Plaintiffs in Transactional Class and Derivative Action, 38 DEL. J. CORP. L. 907, 909-10 (2014) (exploring the debate among commentators about the utility of merger litigation); Robert M. Daines \& Olga Koumrian, Merger Lawsuits Yield High Costs and Questionable Benefits, DEALBOOK, N.Y. TIMES (June 8, 2012, 10:38 AM), http://dealbook.nytimes.com/2012/06/08/merger-lawsuits-yield-high-costs-and-questionablebenefits/, archived at http://perma.cc/8V7J-2B6Z (stating that deal litigation may "impose excessive costs on the companies involved and their shareholders" while delivering uncertain benefits).

10. E.g., Browning Jeffries, The Plaintiffs' Lawyer's Transaction Tax: The New Cost of Doing Business in Public Company Deals, 11 BeRKELEY BuS. L.J. 55, 56-59 (2014).

11. Delaware law provides that the court may award plaintiffs' counsel a fee, payable by the corporate defendant, when the litigation produces a benefit to the corporation and its shareholders. Sugarland Indus., Inc. v. Thomas, 420 A.2d 142, 147 (Del. 1980).

12. In re Sauer-Danfoss Inc. S'holders Litig., 65 A.3d 1116, 1136 (Del. Ch. 2011).

13. See, e.g., Transcript of Settlement Hearing and Rulings of the Court at 44 , In re GenProbe S'holders Litig., No. 7495-VCL (Del. Ch. Apr. 10, 2013) [hereinafter Gen-Probe Transcript] ("I recognize that the policy is to encourage stockholder champions to bring meritorious litigation but not to confer unwholesome windfalls that result in excessive and unwarranted lawsuits."). 
vote on the deal. ${ }^{14}$ Our core hypotheses are as follows: First, because amendments should improve the terms of the merger or the quality of the procedures used in reaching a final agreement, amendment settlements should increase shareholder voting in favor of the merger. In contrast, because forced disclosures should produce negative information about the merger, we hypothesize that disclosure-only settlements should decrease shareholder voting in favor of the merger.

Our empirical tests draw upon a hand-collected sample of 453 mergers involving publicly traded target companies announced from 2005 and completed through 2012 along with proxy-voting statistics provided to us by Institutional Shareholder Services (ISS) over the same period. Although in theory it would be best to test the effect of nonpecuniary relief by comparing shareholder votes before and after the settlement, such a comparison is not possible because shareholder votes are tallied only once, when the polls are closed at the meeting to approve the merger agreement. As a result, our tests take the form of regressions. Our regression analyses compare votes cast in cases involving amendment settlements and disclosure-only settlements to votes in other mergers.

Our tests yield two main empirical results. First, we find weak support for our first hypothesis-that is, that amendment settlements increase shareholder voting in favor of a transaction. Second, and more importantly, we find no support for the second hypothesis - that is, disclosure-only settlements do not appear to affect shareholder voting in any way. We also find only weak evidence that consideration-increase settlements increase shareholder voting in favor of a transaction. To gauge the significance of our findings, we also tested the effect of several other variables on shareholder voting, including transaction size and premium paid, the proxy advisors' recommendation and institutional ownership, and the jurisdiction of settlement. We find that transaction value and the proxy advisors' recommendation have a significant effect on shareholder voting; the other variables do not.

The implication of these findings is clear. If disclosure settlements do not affect shareholder voting, it is difficult to argue that they benefit shareholders. Accordingly, the basis upon which courts are awarding fees to plaintiffs' counsel disappears. Moreover, the illusory benefit of supplemental disclosure must be weighed against the clear cost of merger litigation-including litigation expense as well as delay and uncertainty. Accordingly, our Article proposes that the Delaware courts stop awarding fees for disclosure-only settlements. This reform would reduce the

14. Some settlements provide for a combination of relief. We treat settlements that both amend the merger agreement and provide supplemental disclosures as "amendment settlements." See infra note 137. 
incentive for plaintiffs' attorneys to bring weak merger cases. To the extent that merger disclosures are meaningfully deficient, we argue that plaintiffs should be required to litigate challenges to disclosure quality under the federal securities laws. This would have the effect of efficiently specializing litigation challenges while reducing plaintiffs' counsels' ability to use disclosure as a negotiating point to justify a fee award.

We also argue that state court merger litigation has had the perverse effect of creating a substantive state law of disclosure that is litigated almost exclusively within the artificial context of settlement approval rather than in truly adversarial proceedings. This state law exists within the shadow of federal regulation of mergers, which imposes extensive and explicit disclosure obligations on publicly traded companies. We suggest that the duplication is unnecessary and problematic. Specifically, federal law is expressly tailored to achieving an appropriate balance in disclosure requirements and addressing disclosure deficiencies that are substantially likely to influence the voting decision-that is, material misrepresentations or omissions. In contrast, Delaware law creates an incentive for litigants to generate, and judges to reward, throwaway disclosures that are designed simply to end litigation and generate a release. ${ }^{15}$ These settlements produce disclosures that do not matter to shareholders but are instead simply "useful gravy."16

Our recommendation would restore merger litigation to the balance articulated by the United States Supreme Court in Santa Fe v. Green. ${ }^{17}$ In Santa Fe v. Green, the Court limited the federal securities law cause of action to challenges to disclosure quality, holding that challenges to the adequacy of the merger consideration should be litigated under state law. ${ }^{18}$ We argue that the Delaware courts should reach a similar result-a type of consensual preemption-by concluding that claims about the adequacy of merger disclosure should be litigated under federal law and subject to the materiality threshold and other procedural requirements associated with federal litigation. This efficient specialization would leave for state law issues concerning the fairness of the merger terms.

This Article fits within the body of scholarly literature on representative litigation generally and shareholder litigation in particular. ${ }^{19}$

15. See Sean J. Griffith \& Alexandra D. Lahav, The Market for Preclusion in Merger Litigation, 66 VAND. L. REV. 1053, 1065 (2013) (describing this dynamic).

16. Gen-Probe Transcript, supra note 13 , at 27.

17. Santa Fe Indus., Inc. v. Green, 430 U.S. 462 (1977).

18. Id. at $479-80$.

19. See, e.g., John C. Coffee, Jr., Understanding the Plaintiff's Attorney: The Implications for Economic Theory for Private Enforcement of Law Through Class and Derivative Actions, 86 COLUM. L. REV. 669, 669, 677 (1986) (characterizing plaintiffs' lawyers in representative litigation as "private attorneys general" and theorizing that the litigation and settlement patterns 
This literature has frequently questioned the extent to which representative litigation produces meaningful value for plaintiffs. ${ }^{20}$ Although many articles criticize merger litigation, to our knowledge none supports its conclusion with empirical evidence on the relationship between merger litigation and shareholder voting.

The remainder of this Article proceeds as follows. In Part I we describe the dynamics of merger litigation and note, in particular, the role that courts have played in encouraging litigation challenges through the terms on which they approve settlements and fee awards. Part I explicitly identifies the motivation for our empirical tests: the assumption that these settlements provide a benefit to plaintiff shareholders. In Part II we report our empirical results. Most significantly, we find that amendment settlements affect shareholder voting but that disclosure settlements do not. In Part III we consider the public policy implications of our findings. Part IV identifies and responds to possible objections to our proposa, and in Part V, we briefly sketch out possible methods for implementation. We conclude that Delaware courts should abandon the practice of compensating plaintiffs' lawyers for disclosure-only settlements.

\section{Merger Litigation and Disclosure-Only Settlements}

\section{A. The Anatomy of a Merger Claim}

State court merger litigation is premised upon the traditional fiduciary duties that target-company officers and directors owe to the company's shareholders ${ }^{21}$ in connection with an acquisition, merger, or other business

will reflect their private incentives). Much empirical work on shareholder litigation is devoted to securities fraud class actions. E.g., Stephen J. Choi, The Evidence on Securities Class Actions, 57 VAND. L. REV. 1465 (2004); James D. Cox \& Randall S. Thomas, Mapping the American Shareholder Litigation Experience: A Survey of Empirical Studies of the Enforcement of the U.S. Securities Law, 6 EUR. COMPANY \& FIN. L. REV. 164 (2009).

20. See, e.g., Steven B. Hantler \& Robert E. Norton, Coupon Settlements: The Emperor's Clothes of Class Actions, 18 GEO. J. LEGAL ETHICS 1343, 1347-48 (2005) (describing coupon settlements of dubious value including one where attorneys received $\$ 1.75$ million and consumers received a free box of Cheerios if they kept the original grocery receipt to prove purchase); Roberta Romano, The Shareholder Suit: Litigation Without Foundation?, 7 J.L. ECON. \& ORG. 55, 84-85 (1991) (concluding that "shareholder litigation is a weak, if not ineffective, instrument of corporate governance"); Elliott J. Weiss \& Lawrence J. White, File Early, Then Free Ride: How Delaware Law (Mis)Shapes Shareholder Class Actions, 57 VAND. L. REV. 1797, 1822, 1855-56 (2004) (examining 104 merger class actions filed in Delaware between 1999 to 2001 and finding that merger litigation is lawyer driven, resulting in opportunistic filing and settlement of claims).

21. Although the shareholders of both target and acquiring companies may be unhappy about a planned merger, target shareholders are the typical plaintiffs in merger litigation. In part, this is because target-company shareholders can typically bring a direct action, while the acquirer's shareholders can only bring a derivative suit in the name of the corporation, which is subject to a variety of procedural limitations. Notably, Delaware law has imposed distinctive duties on targetcompany boards in the merger context. See Paramount Commc'ns Inc. v. QVC Network, Inc., 
combination. ${ }^{22}$ In recent years this type of claim has proliferated. ${ }^{23}$ State law fiduciary duties encompass several types of claims. In friendly deals, ${ }^{24}$ the typical claims are a breach of the duty of care and a failure to act in good faith, based on allegations that the board failed to work diligently to maximize the merger price. ${ }^{25}$ The transaction may also trigger a related Revlon ${ }^{26}$ claim. Claims in the context of a controlling shareholder add more traditional allegations of duty-of-loyalty violations. ${ }^{27}$ Finally, shareholders can allege violations of the board's state law duty of disclosure. ${ }^{28}$

The Delaware courts developed the scope of directors' state law disclosure obligations fairly recently. ${ }^{29}$ Although the courts have long

637 A.2d 34, 42 (Del. 1994) (requiring enhanced scrutiny in a stock transaction in which the target company went from being diffusely held to coming under the influence of a controlling shareholder); Revlon, Inc. v. MacAndrews \& Forbes Holdings, Inc., 506 A.2d 173, 181-84 (Del. 1986) (proscribing enhanced scrutiny in a cash transaction involving a break up of the target company); Weinberger v. UOP, Inc., 457 A.2d 701, 711-15 (Del. 1983) (requiring fair dealing and fair price in non-arm's length transactions). But see J. Travis Laster, Revlon is a Standard of Review: Why It's True and What It Means, 19 FORDHAM J. CORP. \& FN. L. 5,7 (2013) (criticizing the so-called "Paramount doctrine" and seeking to articulate a new basis for enhanced scrutiny).

22. For the sake of brevity, we refer to all of these transactions collectively as "mergers."

23. See supra notes 4-6 and accompanying text.

24. Our analysis does not focus on hostile litigation, which raises independent bases for litigation. See Unocal Corp. v. Mesa Petroleum Co., 493 A.2d 946, 953-54 (Del. 1985) (articulating the legal principles applicable in a challenge to a board's adoption of defensive measures initiated in response to a takeover attempt).

25. See, e.g., Robert Thompson \& Randall S. Thomas, The New Look of Shareholder Litigation: Acquisition-Oriented Class Actions, 57 VAND. L. REV. 133, 143, 145-47 (2004).

26. Revlon, 506 A.2d at 182.

27. Thompson \& Thomas, supra note 25 , at 196 .

28. A target board has a disclosure obligation under Delaware law that stems both from the statute and from the board's fiduciary duty. See In re Primedia, Inc. S'holders Litig., 67 A.3d 455, 495 (Del. Ch. 2013) (distinguishing "the statutory obligation to maintain a current and candid merger recommendation ... and the fiduciary duty to disclose material information when seeking stockholder action"). The statutory duty to disclose in connection with merger transactions arises from the requirement that the board make a recommendation concerning the advisability of an intended merger transaction to the shareholders entitled to vote thereon. See DEL. CODE ANN. tit. 8, §251(b) (2011) (requiring that the board adopt the agreement and declare its advisability prior to the shareholder vote). See generally Lawrence A. Hamermesh, Calling Off the Lynch Mob: The Corporate Director's Fiduciary Disclosure Duty, 49 VAND. L. REV. 1087, 1163 (1996) (describing the fiduciary duty of disclosure as "an obligation to use reasonable care in presenting a recommendation for stockholder action and in gathering and disseminating corporate information in connection with that recommendation"). Because shareholders cannot act without information, courts have interpreted the statute to require that the board "disclose fully and fairly all material information within the board's control when it seeks shareholder action." Stroud v. Grace, 606 A.2d 75, 84 (Del. 1992).

29. It is likely that the source is the Delaware Supreme Court's decision in Stroud v. Grace. See Hamermesh, supra note 28, at 1089-91 (describing the development of the duty of disclosure under Delaware corporation law following Stroud). Seeds of a broader disclosure duty under Delaware law appear much earlier. For example, Elliott Weiss and Lawrence White characterize the Court's decision in Lynch v. Vickers Energy Corp., 383 A.2d 278 (Del. 1977), as moving 
recognized that the board in a merger is responsible for providing shareholders with sufficient information to approve or reject the transaction on an informed basis ${ }^{30}$ the suggestion that directors have an independent duty of disclosure and that directors can breach that duty by failing to provide shareholders with information material to the vote is of recent vintage. ${ }^{31}$

Plaintiffs in merger litigation typically ask for equitable relief-most often in the form of an injunction barring consummation of the transaction or requiring a substantial revision of its terms, such as a higher price. ${ }^{32}$ The suits are filed during the pendency of the transaction-usually within days of the public announcement of the merger. ${ }^{33}$ Most of the litigation effort, motions practice, and expedited discovery takes place during the relatively brief window between the merger filing and its closing. ${ }^{34}$ Because claims that are not resolved on motions or settled prior to closing can theoretically be litigated long after closing, creating a potentially significant contingent liability, defendants have a strong incentive to resolve merger claims before

"Delaware law from a posture of requiring less disclosure than federal law requires to a posture of requiring more." Elliott J. Weiss \& Lawrence J. White, Of Econometrics and Indeterminacy: A Study of Investors' Reactions to "Changes" in Corporate Law, 75 CALIF. L. REV. 551, 572 (1987).

30. The seminal case for this proposition is Smith v. Van Gorkom, 488 A.2d 858 (Del. 1985), which held that a board had breached its fiduciary duty by failing to disclose the parameters of the negotiations leading to the company's sale. Id. at 890-92.

31. Delaware's focus on disclosure can be traced to a series of recent cases that required enhanced disclosure in investment banker fairness analysis, as well as in private equity and other conflicted interest transactions. See, e.g., In re Pure Res., Inc., S'holders Litig., 808 A.2d 421, 449-50 (Del. Ch. 2002) (requiring that a target disclose in a tender offer the underlying information used in preparation of a fairness opinion received by its board). See generally Lloyd L. Drury, III, Private Equity and the Heightened Fiduciary Duty of Disclosure, 6 N.Y.U. J.L. \& BUS. 33, 45-48 (2009) (discussing the heightened duty of disclosure employed in Delaware private equity cases in recent years); Blake Rohrbacher \& John Mark Zeberkiewicz, Fair Summary: Delaware's Framework for Disclosing Fairness Opinions, 63 BUS. LAW. 881 (2008) (explaining the duty of disclosure in Delaware law in general and specifically addressing how the duty affects faimess opinions).

32. See, e.g., Verified Amended Class Action Complaint for Breach of Fiduciary Duty at 27, Schacher v. Clausen, No. 8396-VCL (Del. Ch. Mar. 21, 2013) [hereinafter Sauer-Danfoss Complaint] (seeking to have the proposed merger permanently enjoined).

33. See, e.g., In re Sauer-Danfoss Inc. S'holders Litig., 65 A.3d 1116, 1119 (Del. Ch. 2011) (noting that plaintiffs filed their complaint challenging the merger "hours after" the merger plan was announced); DAINES \& KOUMRAIN, supra note 5, at 1 (explaining that, for lawsuits filed in 2012 , "[t]hese lawsuits were filed an average of 14 days after the merger announcement, with plaintiff firms sometimes announcing investigations within hours of the merger announcement").

34. Wilmer CUTLer PiCKering HALE \& DORR LLP, 2013 M\&A REPORT 17 (2013), available at http:/www.wilmerhale.com/uploadedFiles/WilmerHale_Shared_Content/Files/Edito rial/Publication/2013-wilmerhale-ma-report.pdf, archived at http://perma.cc/EN4X-4DGK ("Discovery in these cases can be very fast paced and compressed, since plaintiffs will seek expedited discovery before the shareholder vote on the transaction."). 
the merger closes. ${ }^{35}$ Empirical studies confirm these incentives, finding that nearly $70 \%$ of merger claims settle while the rest are dismissed. ${ }^{36}$ The vast majority of the settlements are concluded prior to the closing of the underlying transaction. ${ }^{37}$

Although the complaints in merger cases typically allege that the merger is substantively unfair, ${ }^{38}$ few cases result in any monetary recovery for the plaintiff class. ${ }^{39}$ Some suits result in amendments to the merger agreement, often to the transaction's deal-protection provisions. ${ }^{40}$ The vast majority of suits, however, settle exclusively for supplemental disclosure in the form of additional information in the merger proxy statement. ${ }^{41}$ The specific disclosures can vary - they may include details of the negotiating process, the manner in which the investment bankers are being compensated in connection with the deal, or specifics about the manner in which the deal or the target company has been valued, either by the board or its advisers. ${ }^{42}$ The supplemental disclosures are provided in an amended proxy statement (Schedule 14A) and are generally disclosed in an 8-K report as well. ${ }^{43}$ Commentators typically refer to such settlements, when

35. For an example of a merger case that resulted in a $\$ 1.347$ billion damage award six years after the deal closed, see In re S. Peru Copper Corp. S'holder Derivative Litig., 52 A.3d 761, 766, 819 (Del. Ch. 2011).

36. E.g., Cain \& Davidoff, supra note 4, at 477.

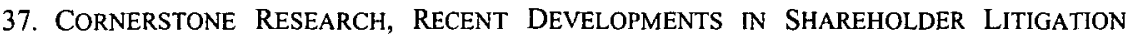
INVOLVING MERGERS AND ACQUISITIONS 9 (2012) [hereinafter RECENT DEVELOPMENTS IN SHAREHOLDER LITIGATION].

38. See, e.g., Sauer-Danfoss Complaint, supra note 32, at para. 76, at 24 (alleging that, as a result of defendants' breach of fiduciary duty, plaintiffs "have not and will not receive their fair portion of the value of Sauer-Danfoss's assets and will be deprived of a fair process").

39. DAINES \& KouMrian, supra note 5, at 6 fig.7. In a small number of cases, however, merger litigation can result in substantial damage awards. For example, in 2012, two cases were settled for large money damages-\$110 million in the deal between El Paso and Kinder Morgan and $\$ 49$ million in the acquisition of Delphi Financial Group, Inc. by Tokio Marine Holdings, Inc. Id. at 6 .

40. See Griffith \& Lahav, supra note 15, at 1093 ("A small number of settlements (approximately thirteen percent) resulted in changes to the merger agreement, most often to the deal-protection provisions ...."). Nondisclosure settlements declined to only $12.5 \%$ of settlements in 2012. Cain \& Davidoff, supra note 5, at 4.

41. See DAINES \& KOUMRIAN, supra note 5, at 6 (observing that in $81 \%$ of merger cases filed in 2012, the only product of the settlement was additional disclosure); Cain \& Davidoff, supra note 4 , at 478 ("Settlements which only require disclosure constitute $55.1 \%$ of the settlement types in the sample and are the most common type of settlement.").

42. See infra notes 106-10 and accompanying text.

43. See, e.g., Zygo Corp., Current Report (Form 8-K) (June 6, 2014), available at http://yahoo.brand.edgar-online.com/displayfilinginfo.aspx?filingid $=10039268 \&$ tabindex $=2 \&$ ty $\mathrm{pe}=\mathrm{html}$, archived at http://perma.cc/Y8DT-DQU9 (disclosing additional information in conjunction with settlement of merger lawsuit). 
they are not combined with some other form of relief, as "disclosure-only" settlements, ${ }^{44}$ a terminology that we will employ in this Article.

The practical explanation for disclosure-only settlements lies in the financial structure of U.S. shareholder litigation. Although parties to litigation normally must finance their own costs, shareholder suits-both derivative suits and class actions-operate under a long-recognized exception to this so-called "American Rule."45 Instead the courts have determined that plaintiffs' lawyers in shareholder litigation can have their fees paid directly by the defendant corporation if the litigation results in a "corporate benefit." ${ }^{, 46}$ The key to plaintiffs' counsel recovering fees is the portrayal of the settlement relief as a corporate benefit. ${ }^{47}$ In a negotiated settlement, defendants will typically not oppose this characterization, nor will they oppose the sought-after fee award, an important element of the bargain. ${ }^{48}$

Average fee awards for the settlement of merger litigation vary widely. In Del Monte, ${ }^{49}$ plaintiffs' counsel received one of the largest fee awards$\$ 22.3$ million for a case that generated a recovery to the plaintiff of $\$ 89.4$ million. ${ }^{50}$ At the low end of the scale is the recent award of $\$ 100,000$ in Gen-Probe. ${ }^{51}$ Given this wide range, reports of average fee awards can easily be misleading. Because most cases settle for disclosure only, however, focusing on disclosure settlements may provide a more realistic view of the incentives under which most plaintiffs' attorneys are operating.

44. E.g., Sumpter, supra note 9, at 678.

45. In re Dunkin' Donuts S'holders Litig., No. 10825, 1990 WL 189120, at *3 (Del. Ch. Nov. 27, 1990).

46. Id.; see also infra subpart I(C).

47. See supra note 8 and accompanying text. The corporate benefit doctrine is actually a variant of earlier collective decisions awarding attorneys' fees out of a common fund in cases in which the litigation produced a common fund for the benefit of the corporation or plaintiff class. Sean J. Griffith, Correcting Corporate Benefit: How to Fix Shareholder Litigation by Shifting the Doctrine on Fees, 56 B.C. L. REV. 1, 37-41 (2015).

48. See In re Sauer-Danfoss Inc. S'holders Litig., 65 A.3d 1116, 1137 (Del. Ch. 2011) (" [O]nce a settlement is agreed, the attorneys for the plaintiff stockholders link arms with their former adversaries to defend the joint handiwork." (quoting Alleghany Corp. v. Kirby, 333 F.2d 327, 347 (2d Cir. 1964) (Friendly, J., dissenting)) (internal quotation marks omitted)); Griffith \& Lahav, supra note 15, at 1093 ("The approval process that courts follow in determining fees awarded to class counsel is, in an important sense, nonadversarial."); Jonathan R. Macey \& Geoffrey P. Miller, The Plaintiffs' Attorney's Role in Class Action and Derivative Litigation: Economic Analysis and Recommendations for Reform, 58 U. CHI. L. REV. 1, 46 (1991) (describing settlement hearings as "pep rallies jointly orchestrated by plaintiffs' counsel and defense counsel").

49. In re Del Monte Foods Co. S'holders Litig., 25 A.3d 813 (Del. Ch. 2011).

50. Transcript of Settlement Hearing at 57-58, Del Monte Foods, 25 A.3d 813 (No. 6027 VCL) [hereinafter Del Monte Transcript].

51. In re Gen-Probe Inc. S'holders Litig., No. 7495-VCL, 2013 WL 1465619, at para. 9 (Del. Ch. Apr. 10, 2013). 
In disclosure-only settlements, the average requested fee award has declined over the past several years, from an average of $\$ 730,000$ in 2009 to an average of $\$ 540,000$ in $2012 .^{52}$ Studies show that the average fee awarded in disclosure-only settlements is approximately $\$ 500,000 .^{53}$

\section{B. Approving Settlement}

Because of the representative nature of merger litigation, the termination of a merger suit by voluntary dismissal or settlement requires court approval. $^{54}$ For most cases that are settled, the court's role at a settlement hearing is threefold: the court must approve the certification of the class; ${ }^{55}$ the court must assess whether the settlement is fair and reasonable; ${ }^{56}$ and the court must decide on the amount of the fee to be awarded to plaintiffs' counsel. ${ }^{57}$ While these steps are independent in theory, as a practical matter, they often collapse. If the court determines that the benefits provided by a settlement are illusory, the plaintiff class will not have received any consideration for the releases that accompany a settlement, and the settlement will not be seen as fair. ${ }^{58}$ In such a case, the court might properly refuse to approve the settlement. This decision might, however, raise questions about the adequacy with which the class has been represented, suggesting that the court should deny class certification. ${ }^{59}$ Similarly, if the court approves the settlement, it has implicitly concluded that the plaintiff class has received something of value, making it difficult to decline to award a fee to class counsel. Notably, the judges in the Delaware Chancery Court are conscious of the incentives that their decisions create with respect to future litigation. ${ }^{60}$ As a result, their

52. DAINES \& KOUMRIAN, supra note 5, at 9 fig.9.

53. See, e.g., Cain \& Davidoff, supra note 6, at 4 tbl.B (reporting the mean and median attorneys' fees for disclosure-only settlements in 2013 as $\$ 511,000$ and $\$ 485,000$, respectively).

54. See FED. R. CIV. P. 23(e) (requiring judicial approval for dismissal or compromise of a class action); accord DEL. CT. CH. R. 23(e).

55. At certification, the judge is charged with determining that the class meets the requirements of the class action rule, including adequacy of representation and of class counsel. Amchem Prods., Inc. v. Windsor, 521 U.S. 591, 618-20 (1997); see also In re Revlon, Inc. S'holders Litig., 990 A.2d 940, 957 (Del. Ch. 2010) (finding counsel was inadequate and therefore declining to approve settlement).

56. In re Triarc Cos., 791 A.2d 872, 876 (Del. Ch. 2001).

57. In re Sauer-Danfoss Inc. S'holders Litig., 65 A.3d 1116, 1135 (Del. Ch. 2011); see also infra subpart $\mathrm{I}(\mathrm{C})$.

58. The settlement agreement typically requires the plaintiffs to release all claims arising out of the merger. Note how this precludes all related claims as a result of the Full Faith and Credit Clause. Griffith \& Lahav, supra note 15, at 1058.

59. E.g., Transcript of Teleconference at 10-11, In re Transatlantic Holdings Inc. S'holders Litig., No. 6574-CS (Del. Ch. Mar. 8, 2013) [hereinafter Transatlantic Holdings Transcript].

60. See, e.g., Sauer-Danfoss, 65 A.3d at 1136 (recognizing that consistency among opinions promotes fairness by establishing baseline expectations). 
opinions frequently seek to benchmark their judgments about settlement value and an appropriate fee level by reference to comparable cases. ${ }^{61}$

In determining whether a proposed settlement is fair and reasonable, the court attempts to weigh the consideration received by the plaintiff class against the strength of the claims that are being released as part of the settlement. As Chancellor Allen explained in Caremark, $^{62}$ a motion seeking judicial approval of a proposed settlement "requires the court to assess the strengths and weaknesses of the claims asserted in light of the discovery record and to evaluate the fairness and adequacy of the consideration offered ... in exchange for the release of all claims made or arising from the facts alleged."

The courts' task in reviewing and approving settlements is complicated by three factors. First, the settlement hearing is likely to be nonadversarial in nature. Second, the factual record presented to the court will be relatively undeveloped. Third, in the absence of an intervening bid, the intended transaction will likely be highly beneficial to shareholders, causing the judge to hesitate to throw additional obstacles in its path. With regard to the nonadversarial nature of the hearing, both plaintiffs and defendants will have a strong incentive to have their agreed-upon settlement approved by the court. Hence, in the absence of objectors, information indicating that the settlement is unfair or unreasonable will not be brought to the court's attention. Second, at a settlement hearing, the court is reviewing a stipulated statement of facts rather than hearing trial testimony or reviewing other direct evidence. Counsel's development of the factual record through discovery may be limited both because of the short window within which merger litigation is conducted and because, once a settlement appears likely, neither side wishes to expend unnecessary resources on additional fact-finding. ${ }^{64}$ As a result, even without the potential for collusion inherent in a nonadversarial proceeding, the court is likely to lack all information necessary to evaluate the settlement. Moreover, the counterfactual analysis required to evaluate the strength of plaintiffs' claims is generally impractical. Third and finally, the court is in a difficult position since experience shows that the vast majority of proposed mergers are approved by shareholders, usually by an overwhelming vote, due to the premium mergers provide shareholders over the current market price. Without an

61. See, e.g., id. (determining an appropriate fee award by comparing past fee awards granted by the court in similar cases).

62. In re Caremark Int'l Inc. Derivative Litig., 698 A.2d 959 (Del Ch. 1996).

63. Id. at 961 .

64. See, e.g., In re Revlon, Inc. S'holders Litig., 990 A.2d 940, $945-46$ (Del. Ch. 2010) (describing a "kabuki dance" of deal litigation in which "real litigation activity ... ceased" once the litigation leadership structure is established). 
intervening bidder, the court is unlikely to throw additional obstacles in the way of a transaction that offers plain benefits to shareholders. ${ }^{65}$ As a result, there is good reason to doubt the ability even of expert jurists to assess the fairness and adequacy of settlements reliably in this context.

Despite these limitations, Delaware judges take seriously their obligation to safeguard the interests of the class by reviewing settlement quality. Evaluating a settlement that provides increased consideration or damages to the plaintiffs is relatively straightforward. Amendment settlements may benefit the shareholders by increasing the likelihood that a third party will make a topping bid. Thus, in Compellent, ${ }^{66}$ Vice Chanceller J. Travis Laster explained that the value of therapeutic changes to a merger agreement "can be estimated as a function of the incremental amount that stockholders would receive if a higher bid emerged times the probability of the higher bid." ${ }^{67}$ The court went on to consider empirical data in order to quantify the potential frequency and size of a topping bid. ${ }^{68}$

Disclosure-only settlements can benefit the shareholder class if the required disclosures allow the shareholders to exercise their voting rights in a more meaningful manner. In Sauer-Danfoss, ${ }^{69}$ for example, Vice Chancellor Laster evaluated the eleven supplemental disclosures called for by the settlement agreement and weighed the extent to which each provided meaningful new information to shareholders. ${ }^{70}$ He concluded that, of the eleven, only one was material. ${ }^{71}$ Similarly in PAETEC, ${ }^{72}$ Vice Chancellor Sam Glasscock considered each individual disclosure required by the proposed settlement and concluded that, except for one, each was of doubtful materiality, trivial, or of marginal utility to shareholders. ${ }^{73}$

To the extent that a court finds a proposed settlement to be of dubious value or, more problematically, inconsistent with its own assessment of the strength of the case,$^{74}$ the court may view the settlement as the product of

65. See, e.g., In re El Paso Corp. S'holder Litig., 41 A.3d 432, 449-51 (Del. Ch. 2012) (noting the court's reluctance to enjoin merger, despite finding of unfair practices, where an injunction might deprive the shareholders of an attractive opportunity to sell their stock).

66. In re Compellent Techs., Inc. S'holder Litig., No. 6084-VCL, 2011 WL 6382523 (Del. Ch. Dec. 9, 2011).

67. Id. at $* 20$.

68. Id. at *21-25.

69. In re Sauer-Danfoss Inc. S'holders Litig., 65 A.3d 1116 (Del. Ch. 2011).

70. Id. at $1128-35$.

71. Id. at 1128 .

72. In re PAETEC Holding Corp. S'holders Litig., No. 6761-VCG, 2013 WL 1110811 (Del. Ch. Mar. 19, 2013).

73. Id. at $* 6-8$.

74. This determination might be assisted through the participation of objectors to the settlement. See, e.g., Prezant v. De Angelis, 636 A.2d 915, 926 (Del. 1994) (remanding settlement for more rigorous inquiry into inadequacy of representation based on objectors' appeal); Griffith 
collusion between plaintiffs' counsel and defense counsel. ${ }^{75}$ In Scully $v$. Nighthawk ${ }^{76}$ Vice Chancellor Laster appointed special counsel to inquire into the possibility of collusion when the litigants concluded a disclosureonly settlement in an alternative forum ${ }^{77}$ after the Vice Chancellor in an earlier hearing had found no colorable disclosure claim but a potentially serious process issue. ${ }^{78}$ The special counsel's brief defined the issue narrowly, ${ }^{79}$ ultimately concluding that collusion had not in fact occurred because the Nighthawk settlement was broadly comparable to other cases ${ }^{80}$

Although not framing his analysis in terms of collusion, Chancellor Leo Strine expressed similar concerns in Transatlantic Holdings. ${ }^{81}$ Having been asked to certify the plaintiffs' class, approve the settlement, and award

\& Lahav, supra note 15 , at 1084-86 (emphasizing the role of objectors in reinvigorating "the adversarial process in an otherwise collusive environment"). The objection rate in class action settlements is low, however. Theodore Eisenberg \& Geoffrey Miller, The Role of Opt-Outs and Objectors in Class Action Litigation: Theoretical and Empirical Issues, 57 VAND. L. REV. 1529, 1533-34 (2004); Jeffries, supra note 10, at 59.

75. The principal factors identified by commentators in identifying collusive settlement practices - fees awarded on top of a settlement that involves limited bargaining and nonpecuniary relief-are present in the settlement of virtually every merger claim. See, e.g., Jonathan R. Macey \& Geoffrey P. Miller, Judicial Review of Class Action Settlements, 1 J. LEGAL ANALYSIS 167, 191-92 (2009) (listing "yellow flags" for collusion, including "settlement bargaining limited to one of the competing groups of plaintiffs' attorneys; settlement with the group of attorneys who present a less substantial threat of carrying the case forward to trial... [and] the award of lucrative and potentially justified attorneys' fees").

76. Scully v. Nighthawk Radiology Holdings, Inc., No. 5890-VCL (Del. Ch. dismissed Dec. 8, 2011).

77. Scully, No. 5890-VCL (Del. Ch. Dec. 23, 2010).

78. Transcript of Courtroom Status Conference at 5-6, Scully v. Nighthawk Radiology Holdings, Inc., No. 5890-VCL (Del. Ch. Jan. 12, 2011).

79. Brief of Special Counsel at 26-27, Scully v. Nighthawk Radiology Holdings, Inc., No. 5890-VCL (Del. Ch. Mar. 11, 2011). The special counsel summarized the issue as follows:

[A] collusive settlement in the context of stockholder deal litigation appears to involve, at its core, an explicit or implicit agreement between counsel for plaintiffs and counsel for defendants to require less consideration for the settling class in exchange for (1) exclusive dealings with particular plaintiffs' counsel and/or (2) more consideration for plaintiffs' counsel. Factors that should give rise to heightened scrutiny for collusiveness include the following: settlement consideration disproportionately weak in comparison to the strength of the claims asserted; settlement with a plaintiff's firm that typically does not litigate aggressively when other, more formidable, firms are involved in the litigation; and an agreement to pay attorneys' fees significantly higher than are typical given the settlement consideration.

Id.

80. Id. at 28-29.

81. Transatlantic Holdings Transcript, supra note 59, at 5-6. The ruling-treating class certification, settlement approval, and the fee award together-is an example of how courts may collapse the analysis of settlement approval, corporate benefit, and the ultimate fee award. See supra notes 55-61 and accompanying text. 
a fee, the Chancellor refused to do all three. ${ }^{82}$ In that case, the two class representatives that had been put forward, one of whom held only two shares, either did not vote on the transaction or did not recall how he had voted. ${ }^{83}$ Class counsel did not perform "any real investigation." ${ }^{84}$ The disclosures amounted merely to additional background information, ${ }^{85}$ and the vote was $99.85 \%$ in favor of the deal with $93 \%$ of the total electorate casting votes. ${ }^{86}$ On the basis of these facts, the court concluded that the plaintiffs had "achieved nothing substantial for the class," and therefore the proposed settlement did not justify releasing the claims of absent parties. ${ }^{87}$

Current settlement practices raise a broader concern. As noted earlier, upwards of $90 \%$ of mergers in recent years faced litigation challenges. ${ }^{88}$ Of the lawsuits filed, $71.6 \%$ settled and nearly $77 \%$ of the settlements were disclosure-only settlements. ${ }^{89}$ In short, plaintiffs negotiate, and courts approve, corrective disclosure in more than $60 \%$ of all transactions. ${ }^{90}$ It is implausible to think that $60 \%$ of all mergers (or $80 \%$ in the last several years) with public company targets and a transaction value of more than $\$ 100$ million, deals that are staffed by top quality lawyers and investment bankers, involve materially deficient disclosures. It is far more likely that merger lawsuits are not filed to correct disclosure problems. The structure of disclosure-only settlements is likely about something else-justification of a fee award to plaintiffs' counsel.

\section{The Fee Award}

Once the court has approved the settlement, it must independently consider the fee award. " $[\mathrm{A}]$ litigant who confers a common ... benefit upon an ascertainable stockholder class is entitled to an award of counsel fees and expenses for its efforts in creating the benefit." Th' The Delaware courts have repeatedly explained that the court has an independent obligation to determine an appropriate fee award, even in a case in which the defendant has agreed not to oppose the plaintiffs' fee request. As the court explained in PAETEC: "This Court has unambiguously held that'In both [contested and uncontested fee applications], the Court has an

82. Transatlantic Holdings Transcript, supra note 59, at 5.

83. Id. at $5-6$.

84. Id. at 8 .

85. Id. at $7-8$.

86. Id. at $10-11$.

87. Id. at 10.

88. See supra notes $5-6$ and accompanying text.

89. Cain \& Davidoff, supra note 4 , at 478 tbl.III.

90. See id. (showing that 385 of 574 litigation cases resulted in corrective disclosure).

91. United Vanguard Fund, Inc. v. Takecare, Inc., 693 A.2d 1076, 1079 (Del. 1997). 
independent duty to award a fair and reasonable fee."92 The court's determination of what constitutes a reasonable fee is based on consideration of the Sugarland $d^{33}$ factors:

(i) the amount of time and effort applied to the case by counsel for the plaintiffs; (ii) the relative complexities of the litigation; (iii) the standing and ability of petitioning counsel; (iv) the contingent nature of the litigation; (v) the stage at which the litigation ended; (vi) whether the plaintiff can rightly receive all the credit for the benefit conferred or only a portion thereof; and (vii) the size of the benefit conferred. ${ }^{94}$

"Among these factors, the last two receive the greatest weight." Thus, although judicial analysis of the fee award frequently includes a discussion of hours expended, the quality of plaintiffs' counsel, and the complexity of the case, the key consideration is typically the size of the benefit conferred. Additionally, the Delaware Supreme Court has repeatedly noted that, where the benefit provided by the litigation is quantifiable, "Sugarland calls for an award of attorneys' fees based upon a percentage of the benefit." 96

The determination of corporate benefit in the context of a fee award is obviously closely related to the assessment of settlement quality described above. Specifically, enhanced disclosure has long been recognized as a potential benefit. ${ }^{97}$ Because of the prevalence of disclosure settlements, the Delaware courts have had frequent occasion to consider the circumstances under which such a settlement justifies a fee award and the relationship between the quality of the disclosures and the size of the reward. As the Court noted in Sauer-Danfoss: "All supplemental disclosures are not equal." ${ }^{\prime 28}$ The courts have sought to achieve relative parity across cases, observing that "[s]imilar disclosures merit similar fee awards." $"$ In

92. In re PAETEC Holding Corp. S'holders Litig., No. 6761-VCG, 2013 WL 1110811, at*5 (Del. Ch. Mar. 19, 2013) (alteration in original) (quoting In re Sauer-Danfoss Inc. S'holders Litig., 65 A.3d 1116, 1137 (Del. Ch. 2011)) (internal quotation marks omitted).

93. Sugarland Indus., Inc. v. Thomas, 420 A.2d 142 (Del. 1980).

94. In re Plains Res. Inc. S'holders Litig., No. Civ.A. 071-N, 2005 WL 332811, at *3 (Del. Ch. Feb. 4, 2005) (citing Sugarland, 420 A.2d at 149-50).

95. In re Celera Corp. S'holder Litig., No. 6304-VCP, 2012 WL 1020471, at *30 (Del. Ch. Mar. 23, 2012); accord In re Anderson Clayton S'holders' Litig., no. 8387, 1988 WL 97480, at *3 (Del. Ch. Sept. 19, 1988) ("'T] $]$ his court has traditionally placed greatest weight upon the benefits achieved by the litigation.").

96. Ams. Mining Corp. v. Theriault, 51 A.3d 1213, 1259 (Del. 2012).

97. See, e.g., Tandycrafts, Inc. v. Initio Partners, 562 A.2d 1162, 1165 (Del. 1989) ("A heightened level of corporate disclosure, if attributable to the filing of a meritorious suit, may justify an award of counsel fees.").

98. In re Sauer-Danfos Inc. S'holders Litig., 65 A.3d 1116, 1136 (Del. Ch. 2011).

99. Id. 
addition, the courts have expressly acknowledged the incentive effect of fee decisions on future litigation and stated that fee awards should encourage counsel to bring meritorious cases. ${ }^{100}$

Recent Delaware decisions display an increasing tendency to apply a common heuristic for awarding fees in disclosure-only cases. The court starts with a fee range based on precedent for the quantity and quality of disclosures provided. ${ }^{101} \mathrm{~A}$ threshold requirement is that the supplemental disclosure be material. ${ }^{102}$ One or two "meaningful" disclosures sets a baseline for the fee range. ${ }^{103}$ Lower quality (less valuable) disclosures result in a downward departure from this benchmark and "particularly significant or exceptional disclosures" are entitled to more. ${ }^{104}$ The fee may then be adjusted further based upon the other Sugarland factors. ${ }^{105}$

The question of what types of disclosures are "meaningful" is a critical aspect of the courts' analysis. Meaningful disclosures will be rewarded (incentivized) with more generous fee awards. Trivial or unhelpful disclosures will be compensated less generously or, in the extreme case, may lead to disapproval of the settlement or denial of any fee award. In his opinion in Sauer-Danfoss, Vice-Chancellor Laster provided three appendices summarizing prior settlements and fee awards in the normal, low, and high fee ranges. ${ }^{106}$ A review of these appendices demonstrates that most meaningful disclosures, for purposes of the courts' analysis, tend to focus on "previously withheld projections or undisclosed conflicts faced by fiduciaries or their advisors." 107 Significantly, the Delaware courts have stressed the importance of information regarding the investment banks'

100. E.g., Dias v. Purches, No. 7199VCG, 2012 WL 4503174, at *4 \& n.29 (Del. Ch. Oct. 1, 2012). The Delaware courts' concern that fee awards provide appropriate incentives, including strong incentives in meritorious cases, is not confined to merger litigation. See, e.g., Ams. Mining Corp., 51 A.3d at 1252 (approving Chancery Court's award of $\$ 300$ million fee on the ground that it "creates a healthy incentive for plaintiff"s lawyers to actually seek real achievement for the companies that they represent in derivative actions and the classes that they represent in class actions" (quoting Transcript of Oral Argument on Plaintiff's Petition for Award of Attomeys' Fees and Expenses and Rulings of the Court at 85, In re S. Peru Copper Corp. S'holder Derivative Litig., 52 A.3d 761 (Del. Ch. 2011) (No. 961-CS)) (internal quotation marks omitted)).

101. See, e.g., Sauer-Danfoss, 65 A.3d at 1136-38 (using three similar cases to arrive at a base range of $\$ 75,000$ to $\$ 80,000$ ).

102. In re Celera Corp. S'holder Litig., No. 6304-VCP, 2012 WL 1020471, at *32 (Del. Ch. Mar. 23, 2012); see also In re PAETEC Holding Corp. S'holders Litig., No. 6761-VCG, 2013 WL 1110811, at *7 (Del. Ch. Mar. 19, 2013) (commencing fee analysis by determining that, because the package of settlement disclosures contained at least one material disclosure, the settlement was fee eligible).

103. Sauer-Danfoss, 65 A.3d at 1136.

104. Id. at 1136-37.

105. Id. at 1135-36.

106. Id. at apps. A, B \& C.

107. Id. at 1136 . 
compensation and potential conflicts. ${ }^{108}$ As Vice Chancellor Glasscock recently explained: "The materiality of a disclosure of a conflicted financial advisor does not necessarily depend on whether the conflict actually harmed the sales process." ${ }^{109}$ Less meaningful disclosures, by contrast, include minor corrections or disclosure of further details concerning, for example, discount rates, negotiation process, and valuation opinions. ${ }^{110}$

\section{A Framework for Measuring the Value of Nonpecuniary Relief}

As we have summarized, virtually every merger currently faces a litigation challenge. The vast majority of cases settle, but monetary recoveries for shareholder plaintiffs are rare. Courts attempt to evaluate the benefit produced by the proposed settlements and to compensate counsel on the basis of that benefit, but the procedural disadvantages that they face in the process render their judgments highly suspect, especially in the context of disclosure-only settlements. The Delaware courts seem to share this skepticism, given their own oft-repeated characterization of supplemental disclosures as being of marginal utility at best.

We therefore suggest an alternative way of testing the value of supplemental disclosures. Because the purpose of merger disclosure is to inform shareholder voting, it is reasonable to view supplemental disclosure as meaningful if it changes the way reasonable shareholders vote. ${ }^{11}$ Furthermore, it is reasonable to hypothesize that merger litigation is only effective if it produces the disclosure of new negative information about the merger. This is because the defendant corporation, without the prod of shareholder litigation, already has an incentive to disclose positive information in order to win approval of the transaction and minimize dissent. $^{112}$ However, the transacting parties might prefer to conceal negative information to reduce the risk that shareholders will refuse to approve the transaction. Putting these two insights together, it seems clear

108. See, e.g., David P. Simonetti Rollover IRA v. Margolis, No. 3694-VCN, 2008 WL 5048692 , at $* 8$ (Del. Ch. June 27,2008 ) (" $[\mathrm{I}] \mathrm{t}$ is imperative for the stockholders to be able to understand what factors might influence the financial advisor's analytical efforts.").

109. In re PAETEC Holding Corp. S'holders Litig., No. 6761-VCG, 2013 WL 1110811, at *7 (Del. Ch. Mar, 19, 2013).

110. Sauer-Danfoss, 65 A.3d at 1143 app. B.

111. See, e.g., TSC Indus., Inc. v. Northway, Inc., 426 U.S. 438, 439 (1976) (“An omitted fact is material if there is a substantial likelihood that a reasonable shareholder would consider it important in deciding how to vote."); Transatlantic Holdings Transcript, supra note 59, at 4 (stating that the real question in evaluating a disclosure settlement is whether the supplemental disclosures are "in any meaningful way of utility to someone voting on the merger").

112. See Frank H. Easterbrook \& Daniel R. Fischel, Mandatory Disclosure and the Protection of Investors, 70 VA. L. REV. 669, 683 (1984) (explaining that, without disclosure, "[i]nvestors would assume the worst, because, they would reason that if the firm had anything good to say for itself it would do so"). 
that for supplemental disclosures to be meaningful, they must have a negative impact on shareholder voting in favor of the merger. This leads to a testable hypothesis: disclosure-only settlements should reduce shareholder votes in favor of the deal.

Amendment settlements are different. The principal benefit of an amendment is its potential to increase the value of the merger. An amendment that increases the merger price is of obvious value to shareholders without regard to its effect on the vote. Most amendment settlements do not increase the merger consideration but instead alter an agreement's deal-protection provisions, perhaps reducing a termination fee or increasing a go-shop period. ${ }^{113}$ The value of these amendments is in their potential to increase the chance of a subsequent higher bid. ${ }^{114}$ Concededly, amendment settlements rarely lead to higher bid prices. ${ }^{115}$ Nevertheless, reducing deal protections arguably improves the quality of the market check. As a result, even when amendments do not result in a higher bid, they arguably should increase shareholder confidence in the economics of the deal. Our second core hypothesis then is that merger litigation resulting in an amendment settlement should increase shareholder support for the merger.

In the Part that follows, we identify and test our core hypotheses. We also test a number of ancillary hypotheses relating to shareholder voting. High-premium deals, for example, should lead to more favorable votes than low-premium deals. Deals recommended by proxy advisory firms ought to result in more favorable votes than deals for which those firms recommend a vote against the transaction. Additionally, building upon the discussion above, we hypothesize that attorneys' fees are an ex post facto assessment of merits in merger litigation and thus that, at least in disclosure cases, for the reasons articulated above, higher fees should correspond to fewer votes in favor of the merger.

113. On deal protections generally, see Steven M. Davidoff \& Christina M. Sautter, Lock-Up Creep, 38 J. CORP. L. 681 (2013).

114. In re Compellent Techs., Inc. S'holder Litig., No. 6084-VCL, 2011 WL 6382523, at *1 (Del. Ch. Dec. 9, 2011).

115. See DAINES \& KoUMRIAN, supra note 5 , at 6 \& fig. 7 (explaining that the parties in only 1 of 119 settling lawsuits in 2012 acknowledged that the settlement contributed to an increase in the merger price). In any event, we would lose what overbids would occur from our dataset as a result of the research design described below. See infra subpart II(A). 


\section{Empirical Analysis of Merger Settlements and Shareholder Voting}

\section{A. Our Sample Set}

Our sample contains all of the transactions listed in the FactSet MergerMetrics $^{116}$ database and announced from 2005 through 2012 that meet the following criteria: (1) the target is a U.S. firm publicly traded on the New York Stock Exchange, American Stock Exchange, or NASDAQ; (2) the transaction size is at least $\$ 100$ million; (3) the offer price is at least $\$ 5$ per share; (4) a merger agreement is signed and publicly disclosed through a filing with the Securities and Exchange Commission (SEC); and (5) the transaction has been completed as of the end of 2012. Information on transactions and litigation is drawn from the dataset used in a prior piece by one of the coauthors. ${ }^{117}$

For shareholder voting outcomes and meeting dates we obtain information from the Factset Proxy Data service. We supplement this with information provided by ISS and by hand review of public filings. We also search press wire services and news databases. ISS recommendations are obtained from ISS itself. We then merge in institutional ownership data from the Thomson Reuters database and stock price information from the Center for Research in Security Prices (CRSP) database. We also search by hand in the Bloomberg Law database to determine if appraisal rights were exercised for Delaware incorporated targets. We drop duplicate variables and variables for which we have no voting results information. A substantial number of transactions do not report any voting results even though such a reporting is required under the securities laws. ${ }^{118}$ We arrive at a sample size of 453 deal observations.

116. More information about the database can be found at FACTSET MERGERS (2014), https://www.mergermetrics.com, archived at http://perma.cc/7U34-82CR.

117. Cain \& Davidoff, supra note 4, at 486-87.

118. Effective as of February 28, 2010 the SEC changed its disclosure rules to require that the outcome of shareholder votes be reported on a Form $8-\mathrm{K}$ filed within four business days after the end of the meeting at which the vote occurred. Proxy Disclosure Enhancements, 74 Fed. Reg. $68,334,68,335$ (Dec. 23, 2009) (to be codified at pts. 229, 239, 240, 249, 274).

Previously, these results were only required to be disclosed on the issuer's next-filed Form 10$\mathrm{Q}$ or Form $10-\mathrm{K}$. Id. at 68,349 . However, a takeover is often completed and the issuer's shares deregistered before this four-business-day period has elapsed. In those circumstances a Form 8-K filing is not required. Id. This was true even before the rule revisions when a $10-\mathrm{Q}$ or $10-\mathrm{K}$ could be due weeks or months after the acquisition's completion. Even when the acquisition occurs more than four business days after the shareholders' meeting, issuers sometimes appear to ignore the filing requirements and do not report results. The result is that of our sample size of 822 merged transactions, we have voting data for approximately half -453 . We were unable to find reported voting results for the remaining issuers. We thank Jennifer Shotwell of Innisfree for explaining why we could not find voting results for so many mergers in our sample. In addition, we excluded transactions where the reported results were approximate rather than exact. 


\section{B. Descriptive Statistics}

Set forth in Table I(A) are statistics on the number of transactions in our sample set, the value of these transactions, and transaction offer premia.

\begin{tabular}{lcccccc}
\hline $\begin{array}{l}\text { Table I(A) Transaction Values and } \\
\text { Premiums (\$\$MM) }\end{array}$ & \multicolumn{1}{l}{ (\$M } & $\underline{\text { Mean }}$ & $\underline{\underline{\text { Dev }}}$ & $\underline{25 \text { th } \%}$ & $\underline{\text { Median }}$ & $\underline{75 \text { th } \%}$ \\
\hline & 453 & $\$ 3,119$ & $\$ 6,902$ & $\$ 328$ & $\$ 957$ & $\$ 3,065$ \\
Transaction Value $(\$ m m)$ & 453 & $\$ 4,272$ & $\$ 9,827$ & $\$ 399$ & $\$ 1,245$ & $\$ 3,697$ \\
Enterprise Value (\$mm) & 453 & $32.73 \%$ & $34.03 \%$ & $14.86 \%$ & $26.45 \%$ & $41.30 \%$ \\
Initial Premium & 453 & $33.37 \%$ & $34.47 \%$ & $15.17 \%$ & $26.97 \%$ & $41.95 \%$ \\
Final Premium & & & & & &
\end{tabular}

Median transaction value across our sample size is $\$ 957$ million. Mean transaction size is a significantly higher $\$ 3.119$ billion, showing that the sample is right skewed with a standard deviation for transaction value of $\$ 6.902$ billion. The median initial offer premium as calculated thirty days prior to announcement of the transaction is $26.45 \%$. Final offer premium is calculated identically and is a slightly higher $26.97 \%$ showing that there is some increase in offer premium over announced and completed transactions. These statistics are comparable to prior studies which have found a similar range of size and premiums for transactions. ${ }^{119}$

Panel I(B) sets forth characteristics of the transactions in our sample.

\begin{tabular}{lcc}
\hline \multicolumn{3}{l}{ Panel I(B): Transaction } \\
& $\underline{N}$ & \% All Transactions \\
\cline { 2 - 3 } Total \# Transactions & 453 & $100 \%$ \\
Merger Consideration = Cash & 303 & $66.89 \%$ \\
Auction & 187 & $41.28 \%$ \\
Go Shop & 58 & $12.80 \%$ \\
Going Private & 22 & $4.86 \%$ \\
Management Buy Out & 14 & $3.09 \%$
\end{tabular}

We focus here on transaction characteristics which may affect premium and shareholder voting. 303 or $66.89 \%$ of transactions were all

119. See, e.g., Leonce L. Bargeron et al., Why Do Private Acquirers Pay So Little Compared to Public Acquirers?, 89 J. FIN. ECON. 375, 376 (2008) (stating that the average premium for private-equity-firm acquisitions is $28.5 \%$ ). 
cash consideration, meaning that shareholders were losing a stake in the future combined entity. 187 or $41.28 \%$ transactions involved companies being sold by auction as opposed to a single-bidder negotiation. Auction transactions may be less prone to shareholder objection and therefore receive higher votes because the target company has been more fully shopped to a wider array of possible bidders. $12.80 \%$ of transactions contained a go shop, a provision for a target to solicit bidders after announcement of a merger agreement. These are largely private equity transactions, which themselves comprise $15.89 \%$ of the sample. Conflicted transactions involving management or a controlling shareholder were a smaller part of the sample. Going private transactions comprise $4.86 \%$ of transactions and management buy outs comprise $3.09 \%$ of transactions. Because of the potential these transactions present for self-dealing, it may be that shareholder support levels are lower.

Table I(C) examines litigation rates for our sample.

\begin{tabular}{lcc}
\hline Table I(C): Litigation & & \\
\hline & $\underline{N}$ & $\frac{0 \text { of Total }}{\underline{\text { Litigation }}}$ \\
Litigation & 319 & $100.00 \%$ \\
Settled & 221 & $69.28 \%$ \\
Dismissed & 65 & $20.38 \%$ \\
Multi-State & 133 & $41.69 \%$ \\
Delaware Filing & 142 & $44.51 \%$ \\
Delaware Settlement & 67 & $21.00 \%$
\end{tabular}

Litigation is brought in an average of $70.42 \%$ of transactions across the time period of our study. The rate of litigation increased substantially over the course of our sample period; one recent study found that litigation rates have risen to $92.10 \%$ in $2011 .{ }^{120}$ Our sample matches these findings; the litigation rate in our sample rises from $48.57 \%$ in 2005 to $95.12 \%$ in 2012. For the transactions with litigation, 221 or $69.28 \%$ result in some type of settlement, 65 or $20.38 \%$ are dismissed, and the remainder are still pending or are abandoned.

120. Cain \& Davidoff, supra note 4 , at 469 . As noted earlier, the rate of litigation continues to increase, and litigation was filed in $97.5 \%$ of transactions in 2013 , meaning that virtually every deal was challenged. See supra text accompanying note 6. 
Table II(A) sets forth information on voting outcomes for our sample.

\begin{tabular}{lrrrrrr}
\hline $\begin{array}{l}\text { Table II(A): Voting } \\
\text { Outcomes }\end{array}$ & & & & & & \\
\hline & $\underline{N}$ & $\underline{\text { Mean }}$ & $\underline{\text { St. Dev. }}$ & $\underline{25 \text { th } \%}$ & $\underline{\text { Median }}$ & $\underline{75 \text { th } \%}$ \\
$\begin{array}{l}\text { \% Yes Votes } \\
\text { Per Votes Cast }\end{array}$ & 393 & $96.73 \%$ & $6.41 \%$ & $97.13 \%$ & $99.00 \%$ & $99.70 \%$ \\
$\begin{array}{l}\text { \% Yes Votes } \\
\text { Per Outstanding } \\
\text { Shares }\end{array}$ & & & & & & \\
$\begin{array}{l}\text { \% Yes Votes } \\
\text { Per All Yes \& No }\end{array}$ & 436 & $75.82 \%$ & $8.77 \%$ & $70.65 \%$ & $76.00 \%$ & $81.64 \%$ \\
Votes & 294 & $97.65 \%$ & $5.25 \%$ & $98.03 \%$ & $99.52 \%$ & $99.85 \%$
\end{tabular}

Table II(A) reports shareholder voting outcomes by three different metrics: (1) yes votes as a percentage of all votes cast; (2) yes votes as a percentage of all outstanding shares;and (3) yes votes as a percentage of all yes and no votes cast. The difference between the first and third measurements is that the first measurement includes abstentions and broker nonvotes. In our regressions and data analysis below we employ separately run regressions using all three metrics. We believe that yes votes measured as a percentage of votes cast best captures shareholder sentiment for a transaction. The reason is that it captures the sentiment of those shareholders who choose to be present at the meeting and cast a ballot or abstain. Shareholder failure to vote at all can indicate a lack of support for a transaction, but it may also be caused by a variety of factors that are independent of the merits. ${ }^{121}$ However, by examining all three metrics we provide a robustness check to our results.

The mean percentage of yes votes per outstanding shares is $75.82 \%$ with a standard deviation of $8.77 \%$. However, the median percentage of yes votes as a percentage of votes cast is $99.00 \%$, meaning that half of all transactions get an even higher number of yes votes. The statistics show that shareholder voting in takeover transactions is largely a yes game among shareholders who do cast votes. There is some dispersion among transactions however, and the standard deviation for transactions as a percentage of votes cast is $6.41 \%$. We note that the median percentage of

121. For example, retail investors typically engage in very low levels of voting. See, e.g., Press Release, Broadbridge Fin. Solutions, Inc. \& PwC's Ctr. for Bd. Governance, Broadridge and PwC Announce New Data on 2013 Proxy Voting Trends 1 (June 4, 2013), available at http://media.broadridge.com/documents/Broadridge-PwC-ProxyPulse-Press-Release-6-4-13.pdf, archived at http://perma.cc/UEA8-TRW3 (reporting that $70 \%$ of shares held by retail investors were not voted). 
yes votes when measured against outstanding shares is significantly lower, meaning that a significant number of shares in any contest are not voted. When shares are voted, it is almost always overwhelmingly in support of the transaction.

Table II(B) sets forth descriptive statistics on types of litigation settlements and voting outcomes based on percentage of yes votes per votes cast.

\begin{tabular}{|c|c|c|c|c|c|c|}
\hline \multicolumn{7}{|c|}{$\begin{array}{l}\text { Table II(B): Voting } \\
\text { Outcomes and Litigation } \\
\text { Settlements Per Votes Cast }\end{array}$} \\
\hline Disclosure-Only & $\underline{N}$ & Mean & $\underline{\text { St. Dev. }}$ & $\underline{25 \text { th } \%}$ & Median & 75th $\%$ \\
\hline Settlements & 153 & $97.25 \%$ & $5.60 \%$ & $97.80 \%$ & $99.10 \%$ & $99.70 \%$ \\
\hline $\begin{array}{l}\text { Amendment } \\
\text { Settlement }\end{array}$ & 26 & $97.90 \%$ & $5.78 \%$ & $98.54 \%$ & $99.43 \%$ & $99.84 \%$ \\
\hline $\begin{array}{l}\text { Increase- } \\
\text { Consideration } \\
\text { Settlement }\end{array}$ & $\underline{\underline{12}}$ & $95.64 \%$ & $7.40 \%$ & $96.42 \%$ & $98.84 \%$ & $99.50 \%$ \\
\hline Total & 191 & & & & & \\
\hline
\end{tabular}

The number of observations drops to 191 because we do not have voting information as a percentage of yes votes per votes cast for all observations with litigation, and not all litigation ends in settlement. The median percentage of yes votes for disclosure-only settlements is at $99.10 \%$ with a standard deviation of $5.60 \%$. Amendment settlements had a higher median percentage of yes votes at $99.43 \%$ with a standard deviation of $5.78 \%$. Finally, settlements involving an increase in consideration had a standard deviation of $7.40 \%$ with a median percentage of yes votes at $98.84 \%$.

Table II(C) sets forth voting information by yes votes cast, sorted by ISS recommendations.

\begin{tabular}{|c|c|c|c|c|c|c|}
\hline $\begin{array}{l}\text { Table II(C): ISS } \\
\text { Recommendations } \\
\text { Per Votes Cast }\end{array}$ & & & & & & \\
\hline & $\underline{N}$ & $\underline{\text { Mean }}$ & $\underline{\text { St. Dev. }}$ & 25th \% & $\underline{\text { Median }}$ & 75th $\%$ \\
\hline ISS Rec $=$ No & 15 & $81.72 \%$ & $12.23 \%$ & $70.00 \%$ & $80.90 \%$ & $97.08 \%$ \\
\hline ISS Rec $=$ Yes & 376 & $97.31 \%$ & $5.29 \%$ & $97.36 \%$ & $99.03 \%$ & $99.70 \%$ \\
\hline
\end{tabular}


As the table shows, there is a large disparity in voting outcomes between a positive ISS recommendation and a negative one. ${ }^{122} \mathrm{~A}$ transaction with a "yes" ISS recommendation has a median percentage of yes votes per votes cast of $99.03 \%$. A transaction with a "no" ISS recommendation has a median percentage of yes votes per votes cast of $80.90 \%$. In unreported statistics we find that the median percentage of yes votes as a percentage of the outstanding shares for a transaction with an ISS "no" recommendation is $66.88 \%$ compared to $76.51 \%$ for a "yes" recommendation. We also find similar results when we examine yes votes as a percentage of total yes and no votes. In those circumstances the median percentage of yes votes as a percentage of yes and no votes is $82.01 \%$ for a "no" recommendation compared to $99.55 \%$ for a "yes" recommendation. We discuss further the possible effect and issues around ISS recommendations below in our regression analysis.

\section{Regression Analysis}

Our regression analysis uses ordinary-least-squares regression. We regress yes votes against the three types of voting metrics: yes votes per (1) votes cast, (2) per outstanding shares, and (3) yes and no votes. We include in our regressions a number of transaction variables, including final premium paid, the proxy advisors' recommendation, and institutional ownership. In the text of our Article we discuss the main findings from our regressions. The full regressions with all variables are set forth in the Appendix. Table III examines how shareholder voting outcomes are affected by the three types of settlements: disclosure-only settlements, amendment settlements, and settlements that produce increased merger consideration.

122. The potential for ISS recommendations to affect voting outcomes has been discussed extensively in the literature. See, e.g., Stephen Choi, Jill Fisch \& Marcel Kahan, The Power of Proxy Advisors: Myth or Reality?, 59 EMORY L.J. 869, 870-77 (2010) (identifying various possible reasons for the relationship). As we discuss below, our findings demonstrate a strong correlation between ISS recommendations and voting outcomes but do not provide evidence of causation. See infra subpart II(C). 


\section{Table III. Shareholder Voting Outcomes and Litigation Settlements ${ }^{123}$}

\begin{tabular}{|c|c|c|c|c|c|c|}
\hline \multirow[t]{2}{*}{ Yes Votes Per } & \multicolumn{2}{|c|}{$\underline{\text { Votes Cast }}$} & \multicolumn{2}{|c|}{ Outstanding } & \multicolumn{2}{|c|}{ Yes and No Votes } \\
\hline & (1) & & (2) & & (3) & \\
\hline \multirow[t]{2}{*}{ Final Offer Premium } & 0.105 & ** & 0.022 & & 0.095 & ** \\
\hline & $(0.03)$ & & $(0.74)$ & & $(0.04)$ & \\
\hline \multirow[t]{2}{*}{ ISS Position } & 0.155 & *** & 0.113 & $* * *$ & 0.124 & $* * *$ \\
\hline & $(0.00)$ & & $(0.00)$ & & $(0.00)$ & \\
\hline \multirow[t]{2}{*}{ Disclosure-Only Settlement } & 0.000 & & 0.011 & & 0.003 & \\
\hline & $(0.98)$ & & $(0.22)$ & & $(0.58)$ & \\
\hline Amendment Settlement & 0.008 & & 0.045 & $* * *$ & 0.017 & \\
\hline & $(0.51)$ & & $(0.01)$ & & $(0.12)$ & \\
\hline \multirow{3}{*}{$\begin{array}{l}\text { Consideration-Increase } \\
\text { Settlement }\end{array}$} & & & & & & \\
\hline & 0.005 & & 0.057 & ** & 0.004 & \\
\hline & $(0.80)$ & & $(0.022)$ & & $(0.809)$ & \\
\hline Observations & 391 & & 423 & & 293 & \\
\hline$R$-squared & 0.2658 & & 0.1228 & & 0.2252 & \\
\hline
\end{tabular}

The variable with the strongest relationship to voting outcomes is the recommendation made by ISS. The ISS variable, which is a dummy variable representing whether ISS recommends a yes or no vote to its clients, is positive and significant at the one percent level in all columns. In our regressions, an ISS "yes" recommendation is associated with an increase in the number of yes votes by anywhere from 11.30 to 15.5 percentage points. The significance of an ISS "yes" recommendation

123. Includes Year-Fixed Effects. $P$-values are in parentheses, with $* * *, * *$, and $*$ denoting statistical significance at the $1 \%, 5 \%$, and $10 \%$ levels, respectively. The following variables are omitted from the table: Initial Offer Premium, Transaction Value (Log), Cash, Auction, Take Private, Go Shop, and Super Majority State. The results for these variables and their definitions are set forth in the Appendix. Final Offer Premium is measured over target's trading price thirty days prior to merger announcement and is the final price paid by the buyer. ISS Position $=0$ means ISS recommended that its' client shareholders do not vote or vote against the transactions. ISS Position = 1 means that ISS recommended that its' client shareholders vote for the transaction. Disclosure Settlement requires the target to make additional disclosure concerning the transaction; Amendment Settlement requires the terms of the transaction to be revised and includes settlements which are both Disclosure and Amendment settlements; and Consideration-Increase Settlement provides for an increase in the consideration payable to target shareholders. ConsiderationIncrease Settlement also includes settlements that have as a component Amendment or Disclosure Settlements. The sample is defined in subpart II(A). See supra subpart II(A). 
explains in part why there is furious lobbying of ISS for its recommendations. It also explains why ISS occupies a controversial role as a proxy adviser. ${ }^{124}$

It is unclear whether our findings with respect to the ISS recommendation reflect causation or simply correlation. In other words, as one of us has observed elsewhere, ISS recommendations may directly influence shareholder votes; alternatively they may simply reflect how shareholders were going to vote anyway. ${ }^{125}$ Furthermore, at least in our sample, ISS "no" recommendations are infrequent. We have only 17 "no" recommendations and 423 "yes" recommendations for the transactions in which we have voting information. ${ }^{126}$

Our variable for final offer premium measures the difference between the final offer price and the target's trading price thirty days before the announcement of the merger. We might expect that mergers involving a higher premium would generate a higher approval rate, and our regressions are consistent with this hypothesis. The variables for final offer premium are significant for the models examining yes votes as a percentage of votes cast and yes and no votes as a percentage of votes. The coefficients on the final offer premium in these models are also positive, meaning that the higher the final offer premium the higher the number of yes votes. We note that our results are not significant in the models for yes votes as a percentage of outstanding shares. We think it is likely that, in these models, the significance of the offer premium is affected by the noisiness of the nonvotes. In addition, it is likely that the premium does not drive the issue of whether or not shareholders vote, although it does drive whether they cast a yes or no vote once they have decided to vote. ${ }^{127}$ This is consistent with our earlier intuition that shareholders fail to vote largely for reasons

124. The SEC recently issued new guidance about investor reliance on proxy advisors. See Proxy Voting: Proxy Voting Responsibilities of Investment Advisers and Availability of Exemptions from the Proxy Rules for Proxy Advisory Firms, U.S. SEC. \& EXCHANGE COMMISSION (June 30, 2014), http://www.sec.gov/interps/legal/cfslb20.htm, archived at http://per ma.cc/LFJ2-KSFH (providing "guidance about investment advisers' responsibilities in voting client proxies").

125. Choi et al., supra note 122 , at 881 .

126. For shareholder voting results reported where the results are per yes and no votes there were 9 ISS "no" recommendations and 284 "yes" recommendations, and for yes votes per outstanding shares there are 16 "no" recommendations and 407 "yes" recommendations.

127. In order to exercise appraisal rights shareholders must vote no, so the intention to exercise appraisal rights may affect shareholder voting. See DEL. CODE ANN. tit. 8, § 262 (2011) ("[A] stockholder ... who has neither voted in favor of the merger or consolidation nor consented thereto in writing . .. shall be entitled to an appraisal ...."). However, in regressions reported in the Appendix containing other settlement variables we do not find the inclusion of a variable reflecting whether shareholders to seek appraisal percentage to be consistently significant. 
that are independent of the merits of the issue on which they are being asked to vote. ${ }^{128}$

In terms of our primary hypothesis-that disclosure-only settlements would have a negative effect on shareholder voting because they reflect the introduction of additional negative information about the merger--our regression results do not support this hypothesis. ${ }^{129}$ Rather we find a noneffect. The coefficient for the variable Disclosure Settlement is not significant in any columns, meaning that in none of our models is a disclosure-only settlement correlated with a significantly different level of shareholder support for the merger. ${ }^{130}$ The lack of a significant relationship between disclosure-only settlements and shareholder voting suggests that shareholders may not value the additional information from these disclosures at least in a way that affects their vote. ${ }^{131}$

128. In unreported regressions we substitute the initial Offer Premium and Final Offer Premium variable with a Low Offer Premium variable. Low Offer Premium is constructed by taking the trailing one-year Final Offer Premium and toggling the variable Low Offer Premium to 1 if it is below the median and 0 otherwise. We find no significant change in the regressions, including the insignificant effects on the Disclosure Settlement variable. In models (1) and (3) above the variable is negative and significant at the $10 \%$ and $5 \%$ level, respectively.

129. As a robustness test we also run time-series analysis to examine if there are any excess returns upon the announcement of a disclosure settlement. We hypothesize two alternative hypotheses based on the fact that once a takeover is announced, the main driver of a stock price is whether or not the takeover will be completed at the price paid. Our first hypothesis is that disclosure settlements will have no effect or a positive effect on share prices. The reason why is that the information is unlikely to significantly affect shareholder voting to an extent significant enough to cause shareholders to vote down the transaction. In this regard, the settlement of the litigation may actually cause a target's share price to increase because any possible delay that may be caused by the litigation, such as an injunction, has been removed or the deal has otherwise now been vetted. Alternatively, if disclosure settlements are valued by shareholders to the extent that the disclosures in a disclosure settlement may influence the outcome of a transaction or otherwise to cause them to agitate to increase the share price or against the transaction, then the share price should go down. In light of these hypotheses, we run a time series analysis using $2,3,4$, and 5 day annual returns as measured against the S\&P 500 index. We find significant results at the $5 \%$ level for all returns with mean excess returns of $.0041, .0062, .0069$, and .008 and $p$-values of $.019, .011, .024$, and .017 , respectively. The results provide support for our first hypothesis, that disclosure settlements have no effect with some evidence that they may be seen as providing deal certainty because of the settlement of the litigation on favorable returns. Alternatively, the favorable result may be seen as shareholder satisfaction with the "vetting" process of this litigation and their subsequent confirmation that this is a good deal due to the settlement and perhaps the additional disclosure. We find no support for the second hypothesis that disclosure settlements provide information materially and adversely affecting the shareholder vote.

130. Because our models are linear, we also run in unreported results the models using the log value of each shareholder vote. We do not find any significant results on the DisclosureSettlement variable.

131. We acknowledge that there also may be some unobserved factor present in these transactions that produces more negative votes. However, we also note the relatively high $R$ squared for our regressions in columns (1) and (2), indicating that we appear to account for many of these variables in our regressions. 
We note the tension between this finding and the general practice of the courts in accepting supplemental disclosure as a benefit to shareholders. Chancellor William Chandler appears to have been correct in concluding in National City ${ }^{132}$ that "[n]o evidence exists that the additional disclosures significantly affected the outcome of the shareholder vote."133 The court nonetheless awarded the attorneys who conducted the litigation that produced these "modest" disclosures a $\$ 400,000$ fee. ${ }^{134}$ In contrast, our findings suggest that Chancellor Strine's similar conclusion in Amylin ${ }^{135}$ was correct: "[N]one of the disclosures anybody got changed the vote." Similarly, to the extent that courts characterize supplemental disclosures as material, meaning information that a reasonable shareholder would consider important in deciding how to vote, our regressions suggest that shareholders do not, in fact, consider the disclosures important.

In contrast, the coefficient on amendment settlements is positive and significant in column (2). The coefficient is .045 , which means that the shareholder yes vote as measured against outstanding shares increases an average of $4.50 \%$ points for amendment settlements relative to other transactions. We do not find these results for other measurements of shareholder voting in columns (1) and (3). The reason for the difference may be that yes votes as a measure of outstanding votes picks up whether shareholders vote or not, while the other metrics are whether shareholders vote yes or no. We do not have an explanation why an amendment settlement may pick up more shareholder votes as opposed to more yes votes. We note that of settlements in our sample involving an amendment to the merger agreement, $55 \%$ involved a reduction of the termination fee. ${ }^{137}$

The variable for consideration-increase settlements is also statistically significant but not significantly more than amendment settlements and

132. In re Nat'l City Corp. S'holders Litig., No. 4123-CC, 2009 WL 2425389, at *6 (Del. Ch. July 31, 2009), aff'd, 998 A.2d 851 (Del. 2010).

133. Id. at *6.

134. Id. at $* 4, * 6$.

135. In re Amylin Pharm., Inc. S'holders Litig., No. 7673-CS (Del. Ch. Feb. 5, 2013).

136. Transcript of Hearing on Peter Doucet's Motion to Intervene and for an Award of Attorneys' Fees and Expenses, Settlement Hearing, and Rulings of the Court at 23-24, In re Amylin Pharm., Inc. S'Holders Litig., No. 7673-CS (Del. Ch. Feb. 21, 2013) [hereinafter Transcript of Amylin Hearing]; see also id. at 23 (making the further point that "not one of [the supplemental disclosures] would any rational investor think was materially important").

137. In unreported regressions, we do not find any significance when we include a disclosureplus variable. These settlements include disclosure plus an amendment. Our findings support one hypothesis- that the disclosure component is an add-on that does not significantly contribute value to the settlement. This finding is also consistent with judge and practitioner criticism that these settlements simply change a term or two of the merger agreement and add on a disclosure component to maximize attorneys' fees. In other words, our findings support the conclusion that shareholders view these settlements as neither value enhancing nor value destroying. 
again only in column (2). This result may seem counterintuitive-if a deal has been litigation tested and that litigation generated a higher price, one might think shareholder approval rates would be significantly higher. One possible explanation is that deals in which the litigation produces a higher price are deals that were suspect to begin with-deals that raise serious issues about process or conflicts of interest. While these concerns warrant an economically meaningful settlement, the price increase negotiated as a result of the settlement may still be lower than the reserve price of some shareholders. ${ }^{138}$

Hypothesizing that because courts attempt to award attorneys' fees in cases that produce meaningful benefits to shareholders, we next test the significance of the attorneys' fee award in predicting the percentage of yes votes.

138. We note that Increase-Consideration Settlements disproportionately occur in goingprivate transactions. 5 of 12 such settlements occur in transactions that are going private, or $41.67 \%$, yet only 22 out of 453 transactions in our sample are going private transactions. 
Table IV. Shareholder Voting, Attorneys' Fees, and Settlements ${ }^{139}$

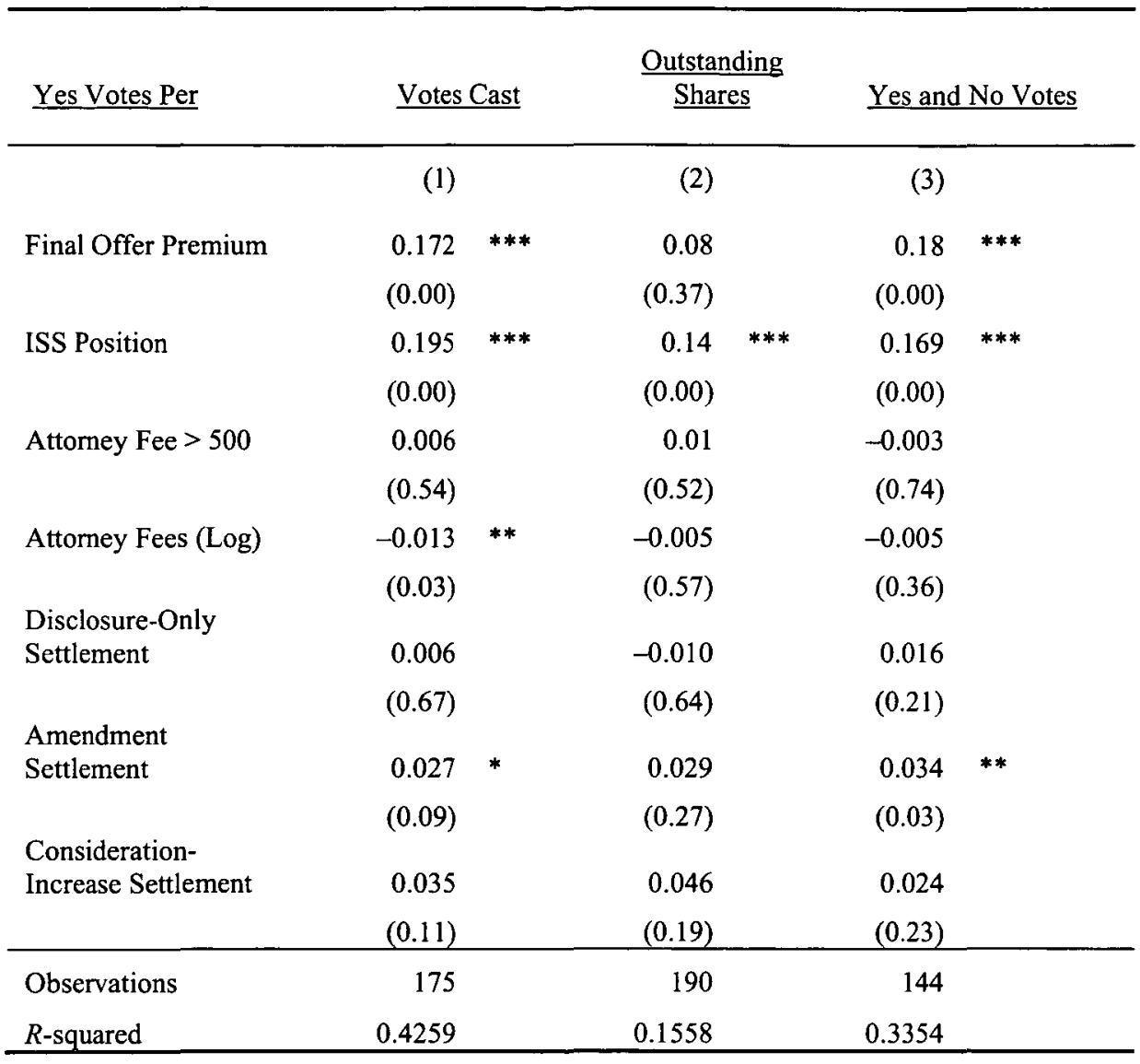

Contrary to the hypothesis that attorneys' fees are ex post facto assessments of the merit of merger litigation, we do not find any consistent relationship between the fee and the shareholder vote. In column (1) we find a slight relationship between attorneys' fees and the percentage of yes votes per vote cast. The coefficient is significant and negative, meaning the lower the attorneys' fee, the lower the number of yes votes as a percentage of votes cast. But the models measuring yes votes as a percentage of

139. Includes Year Fixed Effects. The following variables are omitted from the table: Initial Offer Premium, Transaction Value (Log), Cash, Auction, Take Private, Go-Shop, and Super Majority State. The results for these variables and their definitions are set forth in the Appendix. Attorneys' Fees (Log) is the log value of attorneys' fee awarded in the litigation. Attorneys' Fee > 500 coded $=1$ if the attorneys' fees awarded in the litigation are greater than $\$ 500,000$ and $=0$ if the attorneys' fees awarded are less than $\$ 500,000$. The sample and all other variables are defined in supra note 123. 
outstanding shares and yes and no votes are not significant for this variable. In addition, we do not find significance when we include a dummy variable for whether attorneys' fees are above or below $\$ 500,000$, a threshold that some scholars have found to be the approximate average for disclosure settlements and that has been cited by the courts as a starting point in determining the appropriate award for a meritorious settlement. ${ }^{140}$

These findings are cause for concern. To the extent that courts are making fee determinations to incentivize litigation that is valuable to shareholders, there does not appear to be a significant relationship between the size of the award and the subsequent shareholder vote. Yet if the disclosure does not affect the shareholder vote, it is difficult to see how shareholders benefit from it. ${ }^{141}$ Notably, the coefficients for ISS Position in this model become more significant, implying that a "yes" recommendation for this sample correlates with a percentage change in votes ranging from $14.00 \%$ to $19.50 \%{ }^{142}$

We note that in columns (1) and (3) the coefficient on amendment settlements is positive and significant, meaning those transactions with such a settlement obtain a higher percentage of yes votes. In contrast, the variable consideration-increase settlement is not significant in any model. We are not certain of the reason for the differences in this model for amendment settlements and increased consideration settlements from our prior model in Table III. We note that in this model, we include only settlements with attorneys' fees, meaning that we have a smaller sample than in Table III and that, in addition, our sample sizes for both these categories are substantially smaller than for disclosure-only settlements. It may also be the case that outlier cases, in which the merger is substantively unfair, may be driving the results in these categories.

140. See Gen-Probe Transcript, supra note 13, at 46 ("I try to stick to the ranges [for fee amounts], and I have said repeatedly about the $\$ 450$ to $\$ 500,000$ range as being something that 1 start on."); Cain \& Davidoff, supra note 4, at 482 tbl.IV.B (providing statistics on average fee awards by state).

141. One could hypothesize that shareholder voting rights, like voting rights of citizens, implicate autonomy considerations such that a shareholder derives some value from voting in the same way but while in possession of better information about the choice. Even if this were true, it is not clear that merger litigation is intended to foster these democratic values as opposed to shareholders' economic interests.

142. We also note in the Appendix that in models including the appraisal variable, the disclosure variable is also not significant and negative, meaning that in the presence of a disclosure settlement, there are fewer yes votes as a percentage of outstanding shares. However, the variables for amendment settlement and consideration-increase settlement are significant in all models. 


\section{Table V. Shareholder Voting Outcomes \& Institutional Ownership ${ }^{143}$}

\begin{tabular}{|c|c|c|c|c|c|}
\hline & \multicolumn{3}{|c|}{ All Transactions } & & $\frac{\text { Transaction Value }}{\leq \$ 500 \mathrm{M}}$ \\
\hline & (1) & & (2) & & (3) \\
\hline \multirow[t]{2}{*}{ Institutional Ownership \% } & 0.041 & $* *$ & 0.023 & & -0.043 \\
\hline & $(0.01)$ & & $(0.52)$ & & $(0.74)$ \\
\hline \multirow[t]{2}{*}{ Top 5 Institutional Ownership } & & & -0.108 & & 0.086 \\
\hline & & & $(0.56)$ & & $(0.84)$ \\
\hline \multirow[t]{2}{*}{ Top 10 Institutional Ownership } & & & 0.086 & & 0.141 \\
\hline & & & $(0.58)$ & & $(0.74)$ \\
\hline \multirow[t]{2}{*}{ ISS Position } & & & 0.154 & $* * *$ & 0.232 \\
\hline & & & $(0.00)$ & & $(0.00)$ \\
\hline \multirow[t]{2}{*}{ Disclosure-Only Settlement } & & & -0.003 & & -0.021 \\
\hline & & & $(0.68)$ & & $(0.19)$ \\
\hline \multirow[t]{2}{*}{ Amendment Settlement } & & & 0.009 & & -0.035 \\
\hline & & & $(0.47)$ & & $(0.31)$ \\
\hline \multirow[t]{2}{*}{ Consideration-Increase Settlement } & & & 0.002 & & 0.025 \\
\hline & & & $(0.91)$ & & $(0.75)$ \\
\hline Observations & 393 & & 391 & & 140 \\
\hline$R$-squared & 0.0543 & & 0.2642 & & 0.3439 \\
\hline
\end{tabular}

In our final table, we regress shareholder yes votes as a percentage of votes cast against various institutional ownership variables. We hypothesize that institutional shareholders may be better able to assess merger-litigation settlements, particularly any additional disclosure made upon a disclosure settlement. If this hypothesis is true, we would expect to

143. Includes Year-Fixed Effects. The following variables are omitted from the table: Initial Offer Premium, Final Offer Premium, and Transaction Value (Log). In models (2) and (3), the variable Maximum Institutional Ownership is also omitted. The results for these variables and their definitions are set forth in the Appendix. Institutional Ownership \% is the percentage of total institutional ownership. Top 5 Institutional Ownership is the percentage ownership of the largest 5 institutional owners. Top 10 Institutional Ownership is the percentage ownership of the largest 10 institutional owners. Institutional ownership for each of these variables is as of the quarter end immediately prior to the shareholder meeting date. The sample and all other variables are defined in supra note 123. 
see settlements have a greater effect on merger votes in companies with high levels of institutional ownership. Measured in a variety of ways, however, we find no effect of institutional ownership on shareholder assessment of merger-litigation settlements. However, the $R$-squared in column (1) is relatively low, meaning that the drivers of voting in this model are attributable to other variables. This implies that while the institutional investor ownership percentage does affect voting, it may be captured by these other variables.

To further test the effect of institutional ownership on shareholder voting, we theorize that in smaller transactions (less than $\$ 500$ million), institutional shareholders may affect the outcome more greatly. In column (3) we do not find this to be the case; the institutional shareholder variable is not significant. We also do not find any significance in these smaller transactions for institutional ownership variables.

We run the same regressions in unreported models using the dependent variable percentage of yes votes per yes and no votes. We find in all models that the disclosure settlement variable is insignificant. Again, the most significant variable for institutional investors is the ISS recommendation, which is positive and significant at the one percent level. Similar to our earlier findings, institutional investors do not appear to find disclosure settlements to be significant.

\section{Policy Implications: Ending Fees for Disclosure Settlements}

The findings in Part II raise serious concerns about the existing state of merger litigation, in which the vast majority of mergers are challenged and the resulting litigation produces a disclosure-only settlement, but the disclosures do not seem to affect shareholder voting on the merger. Insofar as disclosure-only settlements do not provide shareholders with useful information, they are wasteful, clogging the courts and increasing transaction costs for no reason. Nevertheless, the current practice of treating disclosure-only settlements as a shareholder benefit sufficient to entitle plaintiffs' attorneys to a fee award incentivizes attorneys to file claims in order to win those settlements. On the basis of our empirical findings, we argue that this incentive is misplaced.

The fundamental claim in state court merger litigation is based on allegations that the merger process and the merger price are unfair. ${ }^{144}$ It appears that, when plaintiffs' attorneys are unable to demonstrate unfairness, they turn to supplemental disclosures to justify an award of fees for their time and expense. In contrast, private litigation under the federal

144. See generally Weinberger v. UOP, Inc., 457 A.2d 701, 711 (Del. 1983) (defining substantive fairness as involving issues of process and price). 
securities laws focuses precisely on material deficiencies in disclosure against a backdrop of extensive disclosure regulation. ${ }^{145}$ In our view, this is a form of efficient specialization that ought to be recognized as a matter of law. Merger litigation, under state law, should address substantive and procedural fairness. Merger litigation, under federal law, should address disclosure quality.

The U.S. Supreme Court has already taken the first step in this direction, holding in Santa Fev. Green that the federal antifraud provisions do not address issues of merger fairness. ${ }^{146}$ In this Part, we propose that Delaware cooperate by limiting the role of state law in regulating merger disclosure. Specifically, we propose that the courts reject disclosure-only settlements as providing a benefit to shareholders sufficient to justify the award of attorneys' fees, at least in cases involving publicly traded target companies. The subparts that follow develop this proposal in greater detail, explaining how the federal securities laws are better suited to regulating merger disclosure, anticipating and answering objections, and then offering specific suggestions on how the solution might be implemented.

\section{A. Federal Regulation of Merger Disclosure}

The federal securities laws are all about disclosure. ${ }^{147}$ The public offering process has, as its central feature, a detailed disclosure documentthe Registration Statement-the role of which is established by Section 5 of the Securities Act of 1933. ${ }^{148}$ The applicable rules concerning subjects such as prefiling offers, prospectus delivery, liabilities, and due diligence are all designed to enhance the effectiveness of the disclosure mandate. Following an initial public offering, federal law subjects public companies to continued periodic disclosure obligations through the reporting requirements of the Securities Exchange Act of 1934, as amended, and the rules promulgated thereunder. ${ }^{149}$

145. See generally Joel Seligman, Commentary, The Merits Do Matter: A Comment on Professor Grundfest's “Disimplying Private Rights of Action Under the Federal Securities Laws: The Commission's Authority," 108 HARV. L. REV. 438, 456 (1994) (describing the role of private securities fraud litigation in enforcing the federal mandatory disclosure system).

146. Santa Fe Indus., Inc. v. Green, 430 U.S. 462, 477-78 (1977).

147. 1 LOUIS Loss ET AL., FUNDAMENTALS OF SECURITIES REGUlation 10 (6th ed. 2011 ).

148. Securities Act of $1933 \S 5$, 15 U.S.C. $\S 77 f(c)(2012)$.

149. Securities Exchange Act of 1934,15 U.S.C. $\$ \S 78 \mathrm{a}-78 \mathrm{pp}$ (2012). What it means to be a public company is somewhat different for purposes of the registration requirements of the Securities Act and the periodic reporting requirements of the 1934 Act. See Donald C. Langevoort \& Robert B. Thompson, "Publicness" in Contemporary Securities Regulation After the JOBS Act, 101 GEO. L.J. 337, 343-46 (2013) (describing "bifurcation" in the concept of "publicness"). 
Federal law also mandates disclosure in connection with shareholder voting through the federal proxy rules. ${ }^{150}$ As a result, the federal securities laws have long been the primary source of explicit disclosure obligations in connection with mergers and acquisitions involving public companies. ${ }^{151}$ The SEC mandates certain disclosures in the Schedule 14A proxy statement, ${ }^{152}$ and it supplements these requirements with particularized additional disclosures in connection with tender offers and going-private transactions. ${ }^{153}$ Thus, in most cases, the disclosure deficiencies challenged in state merger litigation are located within a federally mandated disclosure document. In addition, the supplemental disclosures that are agreed upon in the settlement of state court litigation are ultimately incorporated into the federally mandated form.

The federal disclosure requirements are primarily rule based. ${ }^{154}$ The federal statutes and the SEC rules thereunder require the disclosure of information concerning many of the same items that are frequently the subject of state law disclosure-only settlements, including valuation procedures, financial advisor opinions, and potential conflicts of interest. ${ }^{155}$ For example, the proxy rules require detailed transaction information, including information relating to reports, opinions, or appraisals given by financial advisors. ${ }^{156}$ Disclosure concerning the selection and compensation of outside financial advisors is likewise required in going-private transactions, along with disclosure of any other material relationships between the company and the advisor. ${ }^{157}$

150. 15 U.S.C. $\S 78 \mathrm{n}(\mathrm{h})(1)(\mathrm{D})$.

151. State corporation law does require corporations to disclose shareholder appraisal rights. E.g., DEL. CODE ANN. tit. 8, § 262(d) (2011); see also Gilliland v. Motorola, Inc., 859 A.2d 80, 85-88 (Del. Ch. 2004) (addressing the disclosure requirements under the appraisal statute).

152. 17 C.F.R. $\$ 240.14 \mathrm{a}-101$ (2014).

153. Id. $\S \S 240.14 \mathrm{~d}-100,240.13 \mathrm{e}-100$.

154. See, e.g., Hillary A. Sale, Public Governance, 81 GEO. WASH. L. REV. 1012, 1023 (2013) (describing how Sarbanes-Oxley replaced flexible state law standards with "firm rules"). See generally Louis Kaplow, Rules Versus Standards: An Economic Analysis, 42 DUKE L.J. 557 (1992) (articulating the distinction between using rules versus standards to regulate).

155. See Wilson v. Great Am. Indus., Inc., 855 F.2d 987, 991, 993-94 (2d Cir. 1988) (holding that in a merger between corporations $\mathrm{A}$ and $\mathrm{B}$, failure to disclose that general counsel of corporation A personally represented senior executives of corporation B and that he and his firm served as counsel to several entities controlled by these executives constituted material omissions); Kas v. Fin. Gen. Bankshares, Inc., 796 F.2d 508, 513 (D.C. Cir. 1986) ("The violation arising from the failure to disclose such a potential conflict of interest does not tum on the failure to disclose a director's true motivations but rather stems from the failure to disclose a fact that puts the shareholder on notice of a potential impairment of the director's judgment."); Joel Seligman, The New Corporate Law, 59 BroOK. L. REv. 1, 38-46 (1993) (discussing disclosure obligations under $13 \mathrm{e}-3$ for going-private transactions).

156. 17 C.F.R. $\S 240.14 \mathrm{a}-101$.

157. Id. $\S 229.1015(\mathrm{~b})$. 
The disclosure requirements of federal law reflect a delicate balance. On the one hand, some commentators argue that, in general, more information is better. ${ }^{158}$ Other commentators argue that even some material disclosures might be counterproductive if they overwhelm investors with too much information that cannot be used properly. ${ }^{159}$ The SEC's disclosure requirements are subject to ongoing debate, public scrutiny, and, on occasion, legal challenge, ${ }^{160}$ as the SEC seeks to strike an appropriate balance both in terms of providing useful information and imposing reasonable costs on market participants. As some commentators have noted, the SEC's rule-making process offers particular advantages in evaluating the costs and benefits of proposed disclosure requirements, such as the opportunity for affected market participants to provide input. ${ }^{161}$

The principal difference between state and federal disclosure mandates in connection with merger transactions is that federal law involves proscriptive rules of general application, whereas Delaware judges articulate disclosure requirements in the fact-specific context of individual transactions. ${ }^{162}$ Under federal law, the failure to disclose even material information is not actionable unless SEC rules specifically mandate disclosure of that information or unless the omission renders other disclosures misleading. ${ }^{163}$ The failure to include all material information in a proxy statement does not violate federal law. ${ }^{164}$ As the Third Circuit explained: "[O]mission of information from a proxy statement will violate

158. See, e.g., Joan MacLeod Heminway, Personal Facts About Executive Officers: A Proposal for Tailored Disclosures to Encourage Reasonable Investor Behavior, 42 WAKE FOREST L. REV. 749, 795 (2007) (arguing for codification of disclosure rules relating to executives' private facts).

159. E.g., Troy A. Paredes, Blinded by the Light: Information Overload and Its Consequences for Securities Regulation, 81 WASH U. L.Q. 417, 419 (2003); see also Steven M. Davidoff \& Claire A. Hill, Limits of Disclosure, 36 SEATtLE U. L. REV. 599, 603 (2013) ("[T]he role of disclosure in investment decisions is far more limited, and far less straightforward, than is typically assumed.").

160. See, e.g., Going Private Transactions by Public Companies or Their Affiliates, 73 Fed. Reg. 60,090, 60,090-91 (Oct. 9, 2008) (to be codified at 17 C.F.R. pt. 240) (describing and defending proposed amendments to disclosure requirements in connection with going-private transactions); Petition for Review at 1, Nat'l Ass'n of Mfrs. v. SEC, 956 F. Supp. $2 d 43$ (D.D.C. 2013) (No. 12-1422) (challenging the SEC's conflict minerals disclosure requirement).

161. See David Friedman, Note, The Regulator in Robes: Examining the SEC and the Delaware Court of Chancery's Parallel Disclosure Regimes, 113 COLUM. L. REV. 1543, 1573-75 (2013) (arguing that the SEC should codify Delaware's disclosure rules through notice-andcomment rule making and eliminate the existence of two different sets of disclosure requirements).

162. See id. at 1553 ("[T]he fact-specific nature of Chancery decisions differentiates them from the broad, prospective rules typically generated by regulatory agencies.").

163. Resnik v. Swartz, 303 F.3d 147, 151 n.2 (2d Cir. 2002).

164. See, e.g., Perelman v. Pa. Real Estate Inv. Trust, 432 F. Supp. 1298, 1304 (E.D. Pa. 1977). 
[§ 14(a) and Rule 14a-9] if either the SEC regulations specifically require disclosure of the omitted information in a proxy statement, or the omission makes other statements in the proxy statement materially false or misleading." 165

The distinction is perhaps best illustrated with respect to the disclosure of compensation and conflicts of financial advisors. The SEC requires a descriptive summary of the financial advisors' compensation. ${ }^{166}$ Staff interpretations have often required a breakdown of how much of the advisor's fee was fixed versus contingent. ${ }^{167}$ Delaware precedent, in contrast, requires disclosure of "substantial" contingent fees without clearly articulating the standard by which a fee is judged to be substantial. ${ }^{168}$ Likewise, federal law requires the disclosure of "material relationships" existing between the advisor and the other party in the transaction over the prior two years, ${ }^{169}$ but several Delaware decisions have compelled considerably more detailed disclosure about investment banker relationships and potential conflicts. ${ }^{170}$ Finally, Delaware has recently required the disclosure of a financial advisor's interest in a deal, through institutional or personal holdings, while SEC rules are silent on this issue. ${ }^{171}$ Thus, in El Paso ${ }^{172}$ Chancellor Strine termed Goldman's lead banker's failure to disclose a personal $\$ 340,000$ ownership interest in the buyer's stock "very troubling," although it was unclear that disclosure of this interest was required under federal law. ${ }^{173}$

Shareholders can enforce their disclosure rights under federal law through litigation. Rule 14a-9 prohibits fraud in connection with the solicitation of proxies, and the U.S. Supreme Court has held that it provides a private right of action for false and misleading proxy statements. ${ }^{174}$ In addition, to the extent that shareholders sell their stock in connection with a merger, they have a cause of action under SEC rule 10b-5. ${ }^{175}$ The elements

165. Seinfeld v. Becherer, 461 F.3d 365, 369 (3d Cir. 2006) (alteration in original) (quoting Resnik, 303 F.3d at 151) (internal quotation marks omitted).

166. 17 C.F.R. $\$ 229.1015$ (b)(4) (2014).

167. For more information on staff interpretations of the rule, see generally Steven $M$. Davidoff, Fairness Opinions, 55 AM. U. L. REV. 1557, 1592-93 (2006).

168. Friedman, supra note 161 , at 1554-56.

169. 17 C.F.R. $\$ 229.1015(\mathrm{~b})(4)$; FIN. INDUS. REGULATORY AUTH., FINRA MANUAL $\$ 5150(\mathrm{a})(3)$ (2008), available at $\mathrm{http} / /$ finra.complinet.com/en/display/display_main.html?rbid= 2403\&element_id=6832, archived at http://perma.cc/6QBN-9PG4.

170. Friedman, supra note 161 , at 1556-58.

171. See id. at 1553 (comparing Delaware decisions to the SEC's "lax" rules for disclosure of financial advisors' conflicts).

172. In re El Paso Corp. S'holder Litig., 41 A.3d 432 (Del. Ch. 2012).

173. Id. at 442 .

174. J.I. Case Co. v. Borak, 377 U.S. 426, 429-31 (1964).

175. 17 C.F.R. $\$ 240.10 \mathrm{~b}-5$ (b) (2014). 
of proxy fraud and securities fraud are quite similar. Both require a material misstatement or omission, damages, and a causal relationship between the two. ${ }^{176}$

Importantly, liability under federal law turns on materiality. ${ }^{177}$ Misstatements and omissions in federally mandated disclosure documents are actionable if and only if they are material. ${ }^{178}$ In the context of the proxy statement, the Supreme Court stated that a fact is material "if there is a substantial likelihood that a reasonable shareholder would consider it important in deciding how to vote."179 Critically, as Richard Booth has explained, this means that some investors must react to the information. ${ }^{180}$

The federal courts have developed an extensive jurisprudence concerning the materiality requirement. ${ }^{181}$ Courts consider the role of specific statements within the context of the document in which they are contained, the relevance of other disclosures and general information environment applicable to the issuer, the nature of the information involved (including its capacity to affect the market and the degree to which it is speculative or subjective), the importance of the speaker's identity to the materiality determination, and a host of other factors. ${ }^{182}$ Although the legal definition of materiality is broadly inclusive, ${ }^{183}$ courts have also adopted various qualifications to evaluate the specific disclosures in the context of the particular document in which it is contained, the transaction that it involves, and the overall amount of information present in the market. ${ }^{184}$

Private litigation is a viable remedy for truly deficient disclosures in a proxy statement. Federal litigation offers two potential mechanisms for redress. First, federal courts will provide expedited proceedings and issue an injunction mandating corrective disclosure prior to the shareholder

176. Compare Tracinda Corp. v. DaimlerChrysler AG, 502 F.3d 212, 228 (3d Cir. 2007) (describing elements of a claim under Rule 14a-9), with Erica P. John Fund, Inc. v. Halliburton Co., 131 S. Ct. 2179, 2184 (2011) (listing elements of a violation of Rule 10b-5). The Supreme Court has reserved the question of whether scienter, which is required in a private action under Rule 10b-5, is also required under Rule 14a-9. Va. Bankshares, Inc. v. Sandberg, 501 U.S. 1083, 1090 n.5 (1991).

177. Notably, the federal courts have interpreted the materiality requirement analogously with respect to proxy fraud and federal securities fraud. Heminway, supra note 158 , at 759 .

178. TSC Indus., Inc. v. Northway, Inc., 426 U.S. 438, 444 (1976).

179. Id. at 449 .

180. Richard A. Booth, The Two Faces Of Materiality, 38 DEL. J. CORP. L. 517, 519 (2013).

181. See Heminway, supra note 158 , at $756-59$ (describing decisional law on materiality).

182. See Matrixx Initiatives, Inc. v. Siracusano, 131 S. Ct. 1309, 1312 (2011) (explaining that "assessing materiality". . "is a fact-specific inquiry"); Heminway, supra note 158, at 756-59.

183. Dale A. Oesterle, The Overused and Under-Defined Notion of "Material" in Securities Law, 14 U. PA. J. BUS. L. 167, 169 (2011).

184. See id. at 184-86 (identifying examples such as the "bespeaks caution" doctrine and the truth-in-the-market exception). 
vote. ${ }^{185}$ Second, federal courts can provide ex post money damages. ${ }^{186}$ That these remedies are meaningful is illustrated by the fact that federal litigation frequently settles for meaningful monetary consideration. For example, in the merger of Bank of America and Merrill Lynch, it was later revealed that Bank of America had learned of massive losses at Merrill Lynch just before the Bank of America shareholder vote on the transaction. ${ }^{187}$ Shareholders filed a federal claim under Rule 14a-9 in the Southern District of New York and subsequently settled, not for a form of nonpecuniary relief, but rather for $\$ 2.4$ billion in money damages. ${ }^{188}$

Notably, federal litigation also addresses the potential for frivolous litigation. In the Private Securities Litigation Reform Act (PSLRA), ${ }^{189}$ Congress adopted a variety of substantive and procedural reforms designed to discourage meritless cases while retaining meaningful litigation challenges. For example, the PSLRA imposes a heightened pleading standard for the allegation of disclosure violations. Pursuant to the PSLRA, to state a claim a complaint must (1) "specify each statement alleged to have been misleading, [and] the reason or reasons why the statement is misleading," ${ }^{190}$ and (2) "state with particularity facts giving rise to a strong inference that the defendant acted with the required state of mind." 191 This standard applies to claims under Rule $14 \mathrm{a}-9$ as well as Rule $10 \mathrm{~b}-5 .{ }^{192}$ Courts have also concluded that many of the procedural reforms of the PSLRA, for example, apply to proxy fraud litigation, such as the stay of discovery pending the resolution of a motion to dismiss. ${ }^{193}$ Similarly, courts have noted that the causation requirement prevents every disclosure

185. E.g., Lone Star Steakhouse \& Saloon, Inc. v. Adams, 148 F. Supp. 2d 1141, 1150 (D. Kan. 2001); Gillette Co. v. RB Partners, 693 F. Supp. 1266, 1267-68, 1295 (D. Mass. 1988).

186. E.g., Gerstle v. Gamble-Skogmo, Inc., 478 F.2d 1281, 1303-04 (2d Cir. 1973).

187. Halah Touryalai, Bank of America Will Pony Up $\$ 2.4$ Billion to Investors over Merrill Lynch Merger, FoRBES (Sept. 28, 2012, 10:45 AM), http://www.forbes.com/sites/halahtouryalai/2 012/09/28/bank-of-america-will-pay-investors-2-4-billion-over-merrill-lynch-merger, archived at http://perma.cc/RCE7-HGC8.

188. Timothy Raub, Final Approval of \$2.4Billion Settlement Granted in Bank of America Securities Suit, LEXISNEXIS LEGAL NEWSROOM LITIG. (Apr. 8, 2013, 4:45 PM), http://www.lexisnexis.com/legalnewsroom/litigation/b/litigation-blog/archive/2013/04/08/finalapproval-of-2-4billion-settlement-granted-in-bank-of-america-securities-suit.aspx, archived at http://perma.cc/9GA6-PJRE.

189. Private Securities Litigation Reform Act of 1995, Pub. L. No. 104-67, 109 Stat. 737 (codified as amended in scattered sections of 15 U.S.C.).

190. 15 U.S.C. $\$ 78 \mathrm{u}-4(\mathrm{~b})(2)(\mathrm{A})(2012)$.

191. $I d . \S 78 \mathrm{u}-4(\mathrm{~b})(1)$.

192. See Little Gem Life Scis. LLC v. Orphan Med., Inc., 537 F.3d 913, 915, 917 (8th Cir. 2008) (applying the heightened pleading requirements under the PSLRA to a claim under Rule 14a-9).

193. See, e.g., Smith v. Robbins \& Myers, Inc., No. 3:12-cv-281, 2012 WL 5479061, at *1-2 (S.D. Ohio Oct. 26, 2012) (applying the PSLRA discovery stay to proxy fraud litigation); Dipple v. Odell, 870 F. Supp. 2d 386, 392-93 (E.D. Pa. 2012) (same). 
failure from constituting a violation of Rule 14a-9. ${ }^{194}$ Accordingly, both federal regulation and federal litigation attempt to strike a balance in terms of the scope of disclosure that they mandate and the extent to which violations of the regulatory requirements can be challenged through litigation.

\section{B. State Law Disclosure Litigation}

Although, as noted above, the core concern of state fiduciary duty litigation with regard to mergers is the substantive fairness of the transaction, state law merger complaints often include disclosure claims. Delaware courts have adopted a materiality requirement that is akin to the federal standard. According to the court in Sauer-Danfoss, in order for supplemental disclosures to constitute a substantial benefit sufficient to justify an award of attorneys' fees, the disclosures must be material. ${ }^{195}$ This standard was applied by Chancellor Strine in Amylin to deny a fee request on the basis of the finding that the supplemental disclosures amounted only to "additional meaningless disclosures that did not materially change the mix of information." 196 Noting that not all information can be disclosed ${ }^{197}$ and that all details, even of a financial advisor's analysis, are not required, ${ }^{198}$ the Chancellor reaffirmed the materiality standard. ${ }^{199}$ The Chancellor emphasized that materiality is best demonstrated by a comparative analysis showing how a set of supplemental disclosures meaningfully altered the information previously available. ${ }^{200}$

Nevertheless, materiality analysis operates differently in Delaware merger litigation from the way it operates in federal securities law cases. First, courts decide Delaware merger cases on an expedited basis, according to the lifecycle of the underlying transaction. ${ }^{201}$ If a case is not disposed of through a motion during the pendency of the transaction, it will most likely

194. See, e.g., Lane v. Page, 649 F. Supp. 2d 1256, 1289 (D.N.M. 2009) ("Omissions that might ultimately be minor in a particular factual scenario, but which contravene an SEC regulation... must satisfy causation requirements, preventing insubstantial violations of disclosure requirements from becoming actionable claims for damages.").

195. In re Sauer-Danfoss Inc. S'holders Litig., 65 A.3d 1116, 1127 (Del. Ch. 2011). Under the federal definition, a disclosure is material if "the omitted fact would have been viewed by the reasonable investor as having significantly altered the 'total mix' of information made available." TSC Indus., Inc. v. Northway, Inc., 426 U.S. 438, 449 (1976)

196. Transcript of Amylin Hearing, supra note 136, at 22.

197. Id. at 24 .

198. Id. at 25 .

199. Id. at 28 .

200. Id. at 30 .

201. See Griffith \& Lahav, supra note 15, at 1063-64 (explaining that both parties to merger litigation will seek expedited processes because of the potential for a transaction delayed by litigation to fall apart). 
be settled prior to the transaction's close so that the transacting parties can eliminate it as a contingent liability. ${ }^{202}$ This means that Chancery Court judges reviewing merger disclosures always do so under substantial time pressure, either in the context of a motion to dismiss or in the context of approving a disclosure settlement. As a result, most of the court's rulings on materiality come in the form of transcript opinions. ${ }^{203}$ Delaware's release of transcript opinions seeks to strike a balance between efficiency of time, on the one hand, and clarity of precedent, on the other. By contrast, federal cases are more frequently litigated postclosing and can offer the more formal, precedent-driven consideration of materiality described above. ${ }^{204}$

Second, Delaware courts analyze the materiality of disclosures in connection with the review and approval of settlements, a judicial act that is typically, as we emphasized above, nonadversarial. ${ }^{205}$ As a result, defendants generally do not oppose and often tacitly support plaintiffs' assertions concerning the materiality of disclosures. ${ }^{206}$ To put this into context, the courts in Delaware are rarely faced with arguments on both sides of questions such as whether a proffered supplemental disclosure is largely duplicative of other information already disclosed to the market or is insufficiently factual or too tentative to be useful. By contrast, federal judges rule on materiality as a critical element establishing fraud. ${ }^{207}$ As a result, the issue is fully briefed and argued by both sides to the dispute. Hence, federal judges routinely receive better information in connection with each materiality determination. When federal judges articulate the basis of their materiality determination in formal judicial opinions, this information produces a higher quality body of precedent that judges can draw upon in future determinations. By contrast, unopposed settlements, as even the Delaware judiciary acknowledges, make poor reference points. ${ }^{208}$

In addition, the structure of state court litigation claims creates an odd bifurcation. The primary allegations of the complaint challenge the merger's substantive and procedural fairness, typically encompassing

202. See supra notes $35-37$ and accompanying text.

203. Griffith \& Lahav, supra note 15 , at 1125-26.

204. See supra subpart III(A).

205. See supra subpart $\mathrm{I}(\mathrm{B})$. In a minority of proceedings there are objectors, but these are often pro se litigants, and their objections while noted do not interfere with the main settlement. See Jeffries, supra note 10 , at 59 ("[T] appealed.").

206. See Griffith \& Lahav, supra note 15, at 1093 (discussing potential for agreement or collusion between litigants seeking to win judicial approval of settlements).

207. See supra note 177 and accompanying text.

208. See In re Sauer-Danfoss Inc. S'holders Litig., 65 A.3d 1116, 1137 (Del. Ch. 2011) ("In actuality, when reviewing an uncontested fee application, the Court suffers from an informational vacuum created when the adversity of interests that drives the common law process dissipates."). 
possible conflicts of interest, failure to shop the company adequately or otherwise maximize the sales price, or concerns about provisions in the merger agreement such as termination fees. In contrast, the incidental disclosure claims are generally not well developed in the complaint nor, because they are incidental, are disclosure claims subjected to careful scrutiny at the pleading stage pursuant to a motion to dismiss. What all of this reveals, of course, is that state court litigation really is not about disclosure.

Consider, for example, the Sauer-Danfoss complaint. ${ }^{209}$ Count III alleges a breach of the defendants' fiduciary duty of disclosure in that " $[t]$ he Recommendation Statement fails to disclose material information, including financial information and information necessary to prevent the statements contained therein from being misleading." ${ }^{210}$ The complaint does not identify a single piece of omitted information as a basis for this claim. Nor does the complaint identify a basis upon which the allegedly omitted information was required to be disclosed. Simply put, the allegations fall woefully short of the pleading standard that would be required to file a federal claim under Rule 14a-9. ${ }^{211}$

Most problematically, perhaps, the merits of the materiality question are not squarely before the state court in merger litigation. State courts address materiality not in connection with deciding fraud claims, but rather in connection with approving negotiated settlements. In this context, the court is not asked to decide whether the proxy would have been materially misleading to investors without the supplemental disclosure but rather whether a negotiated package of supplemental disclosures, once added to the proxy statement, benefits shareholders. ${ }^{212}$ Put in these terms, it is difficult for a court to say that shareholders would not like to know an additional piece of information, especially when there is no adverse party briefing the court on why the additional information provides no real benefit. ${ }^{213}$ Our empirical results, however, are fairly clear that supplemental disclosures do not in fact change shareholder behavior and, in that sense at least, provide no real benefit. The next subpart addresses what ought to be done about it.

\section{Eliminating the State Law Claim for Disclosure}

Delaware courts provide a bounty for plaintiffs' lawyers to settle for disclosure by requiring the defendant corporation to pay their fees. This

209. Sauer-Danfoss Complaint, supra note 32.

210. Id. para. 88 , at 26.

211. See supra notes $189-93$ and accompanying text.

212. Griffith, supra note 47 , at $22-25$.

213. Id. at 21-22. 
bounty is based on the premise that disclosure-only settlements provide a "substantial benefit" to the shareholder class. Our findings demonstrate that this premise is misguided. The benefit produced by disclosure-only settlements is anything but substantial. Indeed, it would be closer to the truth to say that it is imaginary.

The cost of these suits, however, is very real. These suits generate litigation costs-specifically the attorneys' fees on both the plaintiff and defense sides-as well as court costs and the uncertainty and risk created by subjecting every merger to litigation, often in multiple jurisdictions. ${ }^{214}$ The cases also may distort Delaware law, if the Delaware courts seek to accommodate these claims and keep them from migrating to other jurisdictions. ${ }^{215}$ Basic cost-benefit analysis therefore suggests that something ought to be done to significantly reduce these settlements. Our suggestion is simple. We propose that Delaware stop recognizing disclosure-only settlements as a substantial benefit for the purposes of a fee award in class litigation involving public company mergers. ${ }^{216}$

Our rule would have the effect of eliminating the financing for disclosure-only settlements, but only disclosure-only settlements, in state court merger litigation. Our proposal explicitly recognizes that merger litigation can produce substantial shareholder benefit-the Southern Peri ${ }^{217}$ decision, for example, clearly shows that it can-and we do not limit the right of shareholders to sue in connection with mergers. Nor do we seek to address the scope of the duty of disclosure under state law. ${ }^{218}$

Delaware courts have been struggling for several years to accomplish a similar outcome by more modest means-a searching and case-specific inquiry into whether the supplemental disclosures are really

214. See Cain \& Davidoff, supra note 6, at 3 (noting frequency of multijurisdictional litigation).

215. See Cain \& Davidoff, supra note 4, at 495 (observing that Delaware courts tend to award higher fees in cases that may be filed in multiple jurisdictions).

216. We confine our proposed rule to public company mergers because our empirical evidence is limited to that context and also because the proxy rules regulate only publicly traded companies. Delaware courts have recognized a difference between the disclosure obligations of public and private companies in other contexts as well. Compare Skeen v. Jo-Ann Stores, Inc., 750 A.2d 1170, 1174 (Del. 2000) (limiting disclosure obligations in an appraisal case involving a publicly held corporation), with Erickson v. Centennial Beuregard Cellular LLC, No. Civ.A. 19974, 2003 WL 1878583, at *6-9 (Del. Ch. Apr. 11, 2003) (expanding disclosure obligations in an appraisal case involving a privately held corporation and differentiating Skeen on the publicprivate distinction).

217. In re S. Peru Copper Corp. S'holder Derivative Litig., 52 A.3d 761 (Del. Ch. 2011).

218. Others have questioned the utility of a state law duty of disclosure that differs from the duties applicable under the federal securities laws. See, e.g., Friedman, supra note 161, at 157779 (advocating unification of the legal standard through SEC rule making adopting the Delaware duty of disclosure) 
"meaningful." 219 Nevertheless, our empirical results suggest that the inquiry in the context of the settlement approval decision is ineffective. The vast majority of cases settled for supplemental disclosures-in which the lawyers receive a nonzero fee award-appear to have no effect on the shareholder vote. We can find no statistically significant relationship between the amount of attorneys' fees awarded and the quality of the resulting disclosure as measured by its effect on the shareholder vote. ${ }^{220}$ To the extent that the courts are trying to award nominal fees in weak cases in order to discourage nonmeritorious litigation, the practice does not seem to be effective--litigation rates have been consistently increasing even as the average fee award declines in size. It is simply implausible to explain the growth in litigation challenges by a decline in the quality of merger disclosures. Rather, existing doctrine, which treats a disclosure-only settlement as providing shareholders with a substantial benefit, is creating bad incentives.

\section{Elimination of Disclosure-Only Fee Awards as Conceptual Preemption}

The obvious objection to our proposal is that by eliminating fee awards in disclosure-only settlements we reduce the incentive for litigation in cases in which the proxy statement is truly deficient. Moreover, removing the threat of shareholder litigation in these cases might lead to an increase in materially deficient disclosure by eliminating the deterrent effect of disclosure claims. Barring disclosure settlements may open the door to materially deficient disclosure.

Our proposal does not eliminate litigation challenges to merger disclosure, however; it simply relegates those challenges to a highly developed body of law and regulation and a forum specialized in applying that law-litigation under the federal securities laws in federal courts. Federal law is, as we explained, better designed to address merger disclosure standards than Delaware's duty of disclosure, and federal courts are well-situated to enforce that law efficiently. Delaware law and Delaware courts, by contrast, are well-suited to pass on the substantive fairness of merger transactions. We would reserve for state courts the promulgation of legal standards for evaluating the substantive and procedural fairness of mergers, and we would reserve for federal law the regulation of merger disclosure.

Our proposal borrows from and extends the fundamental balance of regulatory authority between Delaware, on the one hand, and the SEC, on 
the other, as articulated by the United States Supreme Court in 1977. In Santa Fe Industries, Inc. v. Green, the Supreme Court considered a challenge under Rule $10 \mathrm{~b}-5$ to a short-form merger pursuant to Delaware law. ${ }^{221}$ The plaintiffs' claim was that the merger was fraudulent because it deprived plaintiffs of the fair value of their stock at an inadequate price. ${ }^{222}$ The Court concluded that this allegation failed to state a claim under federal law. ${ }^{223}$ Substantive fairness is not the same as deception, and the Court held that federal law provides a remedy only for the latter. ${ }^{224}$ With respect to substantive fairness, the Court stated that this was an issue for state corporate law. ${ }^{225}$ The Court refused to federalize this body of law and override state regulatory policies. ${ }^{226}$ The Court thus drew a line with respect to the regulation of mergers: federal law would regulate disclosure quality, and state law would address substantive fairness. ${ }^{227}$

The expansion of directors' disclosure duties under Delaware state law encroaches upon the line articulated by the Court in Santa Fe. Concededly, nothing in the Santa $\mathrm{Fe}$ decision or the federal securities laws precludes states from imposing disclosure duties in connection with mergers that supplement those imposed by federal law. ${ }^{228}$ But the broader message of Santa $\mathrm{Fe}$ is a message about the balance of power and the specialization of expertise. Indeed, the Court in Santa $\mathrm{Fe}$ explicitly noted that the plaintiffs had an appraisal remedy available to them, which would have given them the opportunity to have the Chancery Court conduct a valuation of their stock, but that they had chosen not to pursue that remedy. ${ }^{229}$ By implication, the Court's decision was based in part on the existence and perhaps superiority of state court as a forum for adjudicating claims about merger fairness. Since Santa Fe, the Delaware Courts have developed considerable expertise in understanding and applying complex principles of

221. Santa Fe Indus., Inc. v. Green, 430 U.S. 462, 464-65 (1977).

222. Id. at 467 .

223. Id. at $479-80$.

224. Id. at $475-76$.

225. Id. at 478 .

226. Id at $478-79$.

227. See id. at $478-80$.

228. Indeed, the Exchange Act expressly preserves rights and remedies available under state law, leaving room for federal and state disclosure regimes to exist side by side. See Securities Exchange Act of $1934 \S 28(\mathrm{a})(2), 15$ U.S.C. $\$ 78 \mathrm{bb}(\mathrm{a})(2)$ (2012) ("[T] he rights and remedies provided by this chapter shall be in addition to any and all other rights and remedies that may exist at law or in equity."). But see 15 U.S.C. $\S 78 \mathrm{bb}(\mathrm{f})(1)$ (preempting state court litigation for "covered class actions").

229. Santa $\mathrm{Fe}, 430$ U.S. at $466-67$. 
valuation, ${ }^{230}$ as well as in analyzing the procedures by which mergers and other control transactions are conducted and negotiated. ${ }^{231}$

In contrast, the federal courts have developed expertise both in evaluating disclosure quality and in evaluating the quality of litigation challenging that disclosure. This expertise is enhanced within the subject of merger disclosure because the substantive content of a proxy statement in connection with a shareholder vote on a merger is largely determined by the SEC's disclosure requirements. Thus the federal courts' analyses of disclosure challenges are informed by the choices that the SEC has made in formulating affirmative disclosure requirements and balancing those requirements against competing values. This makes the federal courts particularly well-suited to evaluate the extent to which supplemental disclosures add material value to the information provided in a specific proxy statement.

We argue here that the Delaware courts should follow a similar approach to that taken by the Supreme Court in Santa Fe and restore the conceptual boundary between state and federal regulation. We propose that the courts conclude that claims about the adequacy of merger disclosure should be litigated under federal law (and subject to the materiality threshold established therein), leaving state law to focus on the fairness, both procedural and substantive, of the merger terms.

Our proposal locates merger litigation within the space in which federal and state law potentially overlap and in which both Wilmington and Washington should consider the possibility of upsetting a "well-tuned balance" through greater regulatory intervention. ${ }^{232}$ Federal and state law take very different approaches to the regulation of mergers and, in the same manner that the Supreme Court has recognized the superiority of state mechanisms for evaluating substantive merger fairness, state courts might do well to rethink the intrusion into disclosure duties.

\section{Objections and Responses}

\section{A. Multiforum Litigation}

The core objection to our proposal may be that the hands of the Delaware courts are tied. While they might prefer to refuse to award attorneys' fees in disclosure-only settlements, they face a real risk that, in doing so, they will drive merger litigation outside of Delaware and into

230. See, e.g., In re Emerging Commc'ns, Inc. S'holders Litig., No. Civ.A. 16415, 2004 WL 1305745, at *12-28 (Del. Ch. May 3, 2004).

231. See, e.g., Ams. Mining Corp. v. Theriault, 51 A.3d 1213, 1239, 124449 (Del. 2012).

232. Mark J. Roe, Delaware and Washington as Corporate Lawmakers, 34 DEL. J. CORP. L. $1,16(2009)$. 
other states in which the judges subject proposed settlements to lower levels of scrutiny. ${ }^{233}$ Recall that not only has the percentage of mergers facing a litigation challenge risen, but that mergers today typically face multiple litigation challenges in different fora. If Delaware courts do not pay plaintiffs' lawyers, they will file and settle their cases elsewhere. ${ }^{234}$ Indeed there is evidence that litigants have done precisely that, engaging in forum shopping and then, on occasion, entering into reverse auctions in which they agree to settle cases for limited value as long as they receive a fee award. $^{235}$

While it may be that forum shopping has thus far limited the ability of Delaware to reduce the volume of low-value merger litigation, since the judicial acceptance of forum-selection bylaws, however, the problems associated with multiforum litigation have entered a new phase. ${ }^{236}$ Forumselection bylaws allow a corporation to select, in advance, Delaware court as the exclusive forum for corporate governance disputes. ${ }^{237}$ The bylaws are expressly intended to apply to merger litigation. ${ }^{238}$ Hence, a corporation can effectively opt in to the Delaware approach to merger litigation by adopting a forum-selection bylaw, and, provided that the out-of-state court likewise defers to the bylaw provision, Delaware law will be applied by Delaware courts. ${ }^{239}$

233. See, e.g., John Armour et al., Is Delaware Losing Its Cases?, 9 J. EMPIRICAL LEGAL STUD. 605, 634 (2012) (suggesting that courts in other states will scrutinize proposed settlements and fee awards less carefully); Cain \& Davidoff, supra note 4, at 484-85 (discussing problems presented by multijurisdictional litigation).

234. See John Armour et al., Delaware's Balancing Act, 87 IND. L.J. 1345, 1370-72 (2012) (explaining that Delaware's historical approach to attorneys' fees has been "widely believed to be more generous" but that fee cuts could lead to more out-of-Delaware litigation); Cain \& Davidoff, supra note 4, at 496 ("[S]tate courts compete for litigation and attorneys respond rationally to the incentives provided by settlements . . , and . . fee awards themselves."); Griffith \& Lahav, supra note 15, at 1066-70 (examining a trend of cases moving out of Delaware).

235. See Brief of Special Counsel, supra note 79, at 7 (discussing the danger that counsel will settle for too low an amount in order to secure a fee in a reverse auction situation); John C. Coffee, Jr., Class Wars: The Dilemma of the Mass Tort Class Action, 95 COLUM. L. Rev. 1343, 1370, 1372-73 (1995) (explaining how forum shopping can lead to reverse auctions).

236. See, e.g., Boilermakers Local 154 Ret. Fund v. Chevron Corp., 73 A.3d 934, 942, 963 (Del. Ch. 2013) (concluding that such bylaws were facially valid under the statute as applied to cases arising under the internal affairs doctrine).

237. See id. at $951-52$ (explaining that forum-selection bylaws regulate where stockholders may file suit).

238. Id.

239. Cf. City of Providence v. First Citizens BancShares, Inc., No. 9795-CB, 2014 WL 4409816 , at *1, *5, *11 (Del. Ch. Sept. 8, 2014) (deferring to a forum-selection bylaw in favor of North Carolina). But see Roberts v. Triquint Semiconductor, Inc., No. 1402-02441, slip op. at 9 (Ore. Cir. Ct. Aug. 14, 2014) (refusing to defer to forum-selection bylaw in favor of Delaware). 
We note that we do not, in this Article, address the question of whether or to what extent courts should defer to forum-selection clauses. ${ }^{240}$ Nonetheless, to the extent that courts accept such clauses, they enable our proposed rule to operate as a form of private ordering. Were our proposal to be enacted, shareholders of corporations that adopted forum-selection bylaws would effectively be opting into a rule that barred the funding of disclosure settlements from the corporate treasury. By contrast, shareholders of corporations that did not adopt forum-selection bylaws would effectively be electing to keep open the possibility of paying for a disclosure settlement in an alternative jurisdiction. ${ }^{241}$ Were Delaware to choose the clear rule we propose over its current haphazard approach, shareholders could decide for themselves, via the mechanics of forumselection clauses, which rule was optimal for them.

Notably, even if other states do not uniformly defer to forum-selection provisions, ${ }^{242}$ the cases that our proposal would exclude from the Delaware courts are the weakest ${ }^{243}$ - those in which the Delaware courts have the least interest in channeling deal makers' conduct by critiquing the actions of the parties who are brought before them. ${ }^{244}$ As some commentators have observed, these critiques and exhortations are as vital to the development of Delaware law as the holdings themselves because they guide the conduct of transaction planners in future cases. ${ }^{245}$ We suggest, however, that the Delaware courts can perform these "teaching moments" most effectively not in the cases that settle for disclosures and small attorneys' fee awards but rather those that, like El Paso and Del Monte, produce substantial

240. See generally ATP Tour, Inc. v. Deutscher Tennis Bund, 91 A.3d 554, 560 (Del. 2014) (suggesting deference in the context of a loser-pays bylaw).

241. This assumes, of course, that the alternative jurisdiction does not itself have a rule barring the payment of plaintiffs' attorneys' fees for disclosure settlements, an assumption that may not be warranted for every jurisdiction. See infra notes 272-77.

242. See supra note 239.

243. The message courts appear to be sending in many of these disclosure-only cases is that the plaintiffs' bar should stop bringing such weak cases. See, e.g., In re PAETEC Holding Corp. S'holders Litig., No. 6761-VCG, 2013 WL 1110811, at *6 (Del. Ch. Mar. 19, 2013) (stressing that close judicial scrutiny is warranted, especially "in the context of merger litigation that produces a disclosure-only settlement"). The effect appears to be limited though given the continued high rate of litigation.

244. A good recent example of such an opinion is In re El Paso Corp. Shareholder Litigation, in which Chancellor Strine declined to enjoin the merger but excoriated the conduct of the parties involved. 41 A.3d 432, 434-35 (Del. Ch. 2012). Because the court did not issue an injunction, the opinion is technically all dicta, but the critique of the parties' conduct gives transaction planners a clear sense of what to avoid in future deals.

245. See, e.g., Edward B. Rock, Saints and Sinners: How Does Delaware Corporate Law Work?, 44 UCLA L. REV. 1009, 1097-99 (1997) (remarking that shareholder litigation plays a beneficial role in the creation of corporate norms). 
damage awards and attorneys' fees. ${ }^{246}$ As a result, our proposal should not affect the pedagogical content of Delaware law in any meaningful way and instead sends a message to plaintiffs' counsel to concentrate their efforts on the most problematic cases.

An alternative to the use of forum-selection bylaws would be for the Delaware courts to adopt the restriction on attorneys' fee awards in disclosure-only cases as a part of Delaware's substantive corporate law. As a substantive rule, this limitation would preclude other state or federal courts from awarding fees in these cases under $\mathrm{Erie}^{247}$ and the internal affairs doctrine. We note that a substantive law approach would have the salutary effect of preserving the incentive for Delaware courts to continue their leadership role by maintaining the potential for competition with respect to the "good" merger cases.

\section{B. The Litigation Response to Barring Disclosure-Only Fee Awards}

We have focused in this Article on the incentive effect of settlementonly fee awards. We recognize, however, that our proposal creates an alternative set of incentives that may, in turn, impact future merger litigation. Possible such effects include: (1) reducing merger litigation to the point that it allows bad deals to proceed unchallenged; (2) creating negative spillover effects in other forms of corporate litigation, such as appraisal actions; and (3) shifting to an alternative type of low value settlements in merger litigation. We address each of these in turn.

One challenge to our proposal is that it would undercut what is often seen as the basic value of merger litigation - that is, its ability to serve as a screen for deal quality. According to this view, the real purpose of merger litigation is to identify and prevent bad deals from being consummated. However, because litigants cannot necessarily evaluate deal quality until the case gets into discovery-Del Monte is an example of a transaction that did not show its flaws until shareholder claimants reached discovery ${ }^{248}$ merger litigation must be overinclusive at the filing stage in order to get potentially good cases into discovery. Hence, the argument goes, our proposal inhibits the screening function of merger litigation because it is likely to result either in fewer claims being brought or in fewer claims being

246. The settlement amount in El Paso was $\$ 110$ million (with $\$ 26$ million going to legal fees and expenses), while the settlement amount in Del Monte was $\$ 89.4$ million (with $\$ 23.3$ million going to legal fees and expenses). El Paso, 2012 WL 6057331, at *para. 19; Stipulation and Agreement of Settlement at 10, El Paso, 41 A.3d 432 (No. 6949-CS); Del Monte Transcript, supra note 50 , at 53,58 .

247. Erie R.R. Co. v. Tompkins, 304 U.S. 64 (1938).

248. See In re Del Monte Foods Co. S'holders Litig., 25 A.3d 813, 817 (Del. Ch. 2011) (noting that "[d]iscovery revealed a deeper problem" with the sale process). 
pursued with any real vigor. Because fewer claims are being pursued, the screening function of merger litigation may not function optimally-that is, it may allow bad deals to proceed unchallenged.

First, we acknowledge that our proposal is likely to lead to a reduction in merger litigation overall. This is because the inability to win fees for disclosure settlements will reduce the profitability of merger litigation for plaintiffs' firms on a portfolio basis, creating an incentive to curtail claims activity. This is not necessarily a bad thing. Indeed, in light of the ubiquity of litigation challenges to mergers, we view this as a virtue of our proposal. ${ }^{249}$ What we are advocating simply is a return to the state of merger litigation circa 2003 before the current litigation explosion. In that year, 25 cases were brought or approximately $28.7 \%$ of deals using the same sample criteria that we use in this Article. ${ }^{250}$ We have little reason to believe that this level of litigation exposure was insufficient to deter misconduct.

In addition, the Delaware courts can offset the effect of our proposal completely by simply paying higher attorneys' fees for meritorious cases. Tailoring the fee award more closely to case quality would provide more appropriate incentives than paying counsel a nominal fee in every case, no matter how weak. In contrast, current law seems to encourage plaintiffs' firms to bring weak cases in the hope of winning fees for supplemental disclosures. We would be happy if our proposal resulted in these claims not being brought.

Moreover, a reduction in claims activity is problematic only if good claims and bad claims are equally deterred-in other words, that it is impossible to identify good and bad cases early in the process. We doubt the accuracy of this proposition. There are strong reasons to believe that plaintiffs' firms are able to screen for case quality early in the litigation process and to expend their resources in the highest quality cases. Litigation experience under the federal securities laws subsequent to the adoption of the PSLRA strongly suggests both that plaintiffs' lawyers respond to incentives and that, when the law structures incentives to reward only high quality cases, plaintiffs' lawyers respond. ${ }^{251}$

249. See supra Part III.

250. This number is derived from unreported statistics used in our data compilation for another paper coauthored by one of the authors. C.N.V. Krishnan, Steven Davidoff Solomon \& Randall S. Thomas, Zealous Advocates or Self-Interested Actors? Assessing the Value of Plaintiffs' Law Firms in Merger Litigation (Vanderbilt Univ. Law Sch. Law \& Econ., Working Paper No. 14-25, 2014), available at http://papers.ssm.com/sol3/papers.cfm?abstract_id=2490098, archived at http://perma.cc/G26B-EMEX.

251. See, e.g., Stephen J. Choi, Do the Merits Matter Less After the Private Securities Litigation Reform Act?, 23 J.L. ECON. \& ORG. 598, 622-23 (2007) (empirically testing the effect 
Alternatively, a ban on fee awards in disclosure-only settlements might lead plaintiffs' counsel to shift the nature of the cases they file. One possibility is a shift from fiduciary duty claims to appraisal proceedings. At least one empirical study has found that investors are making growing use of the appraisal remedy ${ }^{252}$ and, at least in some cases, recovering substantially more than the merger consideration. ${ }^{253}$.

To the extent our proposal generates a shift to appraisal proceedings, we would view that shift as an unmitigated benefit for two reasons. First, the Delaware courts are experts in valuation methodology and continue to refine the appraisal proceeding to modernize the mechanism for shareholders to challenge merger price. Second, appraisal focuses directly on the issue that is most central to a merger challenge-are shareholders receiving fair value for their stock? ? $^{254}$ At the end of the day, whatever disclosure or process issues are involved, the primary issue from a shareholder perspective is the merger price. ${ }^{255}$ By focusing exclusively on that question, we view appraisal as the optimal method for providing shareholders with redress. Indeed, as the Delaware courts have explained, the appraisal proceeding may provide shareholders with a better remedy than the standard fiduciary duty claim if the true concern is merger consideration because an appraisal proceeding requires a judicial determination of fair value, while a court will reject a fiduciary duty claim so long as the merger price is "within the range of fairness." difference is illustrated by the Cede \& Co. v. Technicolor ${ }^{257}$ litigation, in which the court determined, in ruling on a breach of fiduciary duty claim, that the merger consideration of $\$ 23 /$ share was fair, ${ }^{258}$ yet in an appraisal proceeding awarded the plaintiffs $\$ 28.41 /$ share. ${ }^{259}$ Accordingly, we view the appraisal proceeding as creating appropriate litigation incentives for

of PSLRA on filing decisions by plaintiffs' attorneys and finding significant effect on the choice of cases filed).

252. See Minor Myers \& Charles R. Korsmo, Appraisal Arbitrage and the Future of Public Company M\&A, 92 WASH. U. L. REV. (forthcoming 2015) (manuscript at 14-18) (documenting a large increase in appraisal activity), available at $\mathrm{http}: / / \mathrm{ssrn}$.com/abstract $=2424935$.

253. See id. (manuscript at 36 tbl.3) (showing the mean amount allocated to shareholder to be much greater with "all appraisal" than with "no appraisal").

254. Id. (manuscript at 1); see also In re Trados Inc. S'holder Litig., 73 A.3d 17, 35 (Del. Ch. 2013) ("The appraisal proceeding seeks a statutory determination of fair value ....").

255. See Trados, 73 A.3d at 78 (finding no breach of fiduciary duty where merger price was determined to be fair).

256. Id.

257. Cede \& Co. v. Technicolor, Inc., 884 A.2d 26 (Del. 2005).

258. Cinerama, Inc. v. Technicolor, Inc. (Technicolor III), 663 A.2d 1156, 1176-77 (Del. 1995).

259. Cede, 884 A.2d at 30. 
both shareholders and their counsel to bring challenges if and only if they have a reasonable chance of recovering additional consideration.

A third possible concern is that our proposal eliminates only one pathway to wasteful settlement while leaving several others, notably amendment settlements and securities claims, completely unaffected. The predictable result of this change, then, is that litigants with weak claims will seek to channel their rent-seeking efforts along these other paths, seeking fees in exchange for meaningless amendments to the merger agreement or, alternatively, seeking to conclude a meaningless disclosure settlement of their securities claim.

Our first response is that we should not allow the perfect to become the enemy of the good. If disclosure-only settlements do not benefit shareholders, they should not be incentivized. This conclusion holds regardless if our proposal does not, at the same time, eliminate other opportunities for rent-seeking by plaintiffs' lawyers. Our second response is to question the extent to which these alternatives provide effective substitutes for disclosure-only settlements. We have reasons to think they do not.

At first glance, amendment settlements seem to be the most promising alternative pathway for plaintiffs' lawyers' rent-seeking efforts. It may be possible for plaintiffs' lawyers to negotiate very small modifications to the merger agreement and then to argue that these modifications benefit the shareholder class. Indeed, this happens today. Studies find that many common merger-agreement amendments involve modest changes to deal protections, such as a slightly longer go-shop period or a slightly smaller termination fee, generally with no observable effect, such as the subsequent appearance of an intervening bidder. ${ }^{260}$ Such changes might become more common were our proposal to be implemented. Moreover, to prevent such amendments from disturbing their bargain, transacting parties could anticipate them in the terms of the original agreement by agreeing to a shorter go-shop period or a higher termination fee at the outset.

While some such behavior may take place, we believe it is generally far less easy to settle for an amendment to the merger agreement than to settle for supplemental disclosures. Our empirical results clearly support this view-in our sample, $13.60 \%$ of settlements are amendment settlements while $80.10 \%$ are disclosure-only settlements. One explanation is that before plaintiffs' lawyers and the target company can agree to amend the merger agreement, they must get the approval of a significant party at interest-namely, the acquiring company. By this point in the process, the

260. See RECENT DEVElopMENTS IN SHAREHOLDER LitTGATION, supra note 37 , at 10 (listing termination fees as a common amendment); Cain \& Davidoff, supra note 4, at 479 (same). 
acquiring company will have invested considerable effort and expense in the merger agreement and, having achieved agreement, will likely be loath to alter it. In addition, even if the amendments are minor, the acquiring party arguably has something meaningful to lose from them, leading the settlement negotiation to be more adversarial in nature. Simply put, the involvement of a third party with something to lose in the transaction inhibits collusion between the plaintiffs' attorney and the defendant. ${ }^{261}$ In contrast, the negotiation of a disclosure settlement involves only the plaintiffs' lawyers and the target corporation, enabling low-value disclosures to be traded more freely. ${ }^{262}$

Furthermore, should the involvement of the counterparty to the merger agreement not be sufficient to prevent litigants from concluding low-value amendment settlements, the Delaware courts could once again become involved. Chancery Court judges have a comparative advantage in evaluating merger agreements generally and deal-protection provisions in particular. There is a large and well-developed body of substantive jurisprudence on the gamut of deal-protection devices-from poison pills and crown-jewel lockups to termination fees and no-talk or no-shop provisions. ${ }^{263}$ The judges of the Chancery Court regularly evaluate how a given provision affected a particular deal and would be especially wellsuited to determine whether a given amendment produced substantial benefit to the shareholder class. ${ }^{264}$

The other obvious litigation alternative is for plaintiffs' lawyers to file disclosure claims under the federal securities laws and to resolve those claims through disclosure-only settlements. As noted earlier, we do not view this alternative as problematic, largely because of the existing body of procedural and substantive requirements designed to limit the potential for

261. The acquiring company is unlikely to go along with whatever the target company and the shareholders' lawyers suggest, potentially viewing the suggested amendments as negotiating gambits and insisting instead upon the deal as agreed.

262. It is true that insofar as the plaintiffs' attorneys' fees are paid by directors and officers (D\&O) insurance, as indeed they typically are, there is theoretically a third party at the tablenamely, the D\&O insurers-who could constrain the ability of plaintiffs and defendants to collude, much as the acquiring company would constrain the parties in the context of an amendment settlement. That the D\&O insurer frequently does not live up to this role, however, is well documented. See TOM BAKER \& SEAN J. GRIFFITH, ENSURING CORPORATE MISCONDUCT: HOW LIABILITY INSURANCE UNDERMINES SHAREHOLDER LITIGATION 138-41 (2010) (discussing the constraints on D\&O insurers' authority and influence over settlements).

263. See, e.g., Omnicare, Inc. v. NCS Healthcare, Inc., 818 A.2d 914, 933-36 (Del. 2003) (evaluating multiple deal-protection devices); Revlon, Inc. v. MacAndrews \& Forbes Holdings, Inc., 506 A.2d 173, 182 (Del. 1986) (analyzing the use of a lock-up agreement).

264. See, e.g., In re Compellent Techs., Inc. S'holder Litig., No. 6084-VCL, 2011 WL 6382523, at *18-26 (Del. Ch. Dec. 9, 2011) (evaluating the benefit conferred to shareholders by modification of the deal protections in a merger agreement). 
frivolous litigation. ${ }^{265}$ Substantively, a federal cause of action is more limited than a state law duty-of-disclosure claim, both because of the threshold materiality analysis and because of the fact that omissions are actionable only in the context of an affirmative duty to disclose. As we have noted, federal courts have developed expertise in the application of these legal standards. ${ }^{266}$ Procedurally, the pleading standard of the PSLRA requires plaintiffs to identify specific misstatements and omissions at the outset rather than filing a boilerplate claim of inadequate disclosure, and the discovery stay prohibits plaintiffs from using the cost of discovery as leverage to induce a settlement. ${ }^{267}$ Studies suggest that the federal courts have been diligent in applying these standards to dismiss weak disclosure claims at an early stage. ${ }^{268}$

\section{A Roadmap to Implementation}

Having laid out our proposal, we briefly consider possible methods of implementation. Because of Delaware's leadership role in corporate litigation, and because of the high percentage of merger targets that are incorporated in Delaware, we look to Delaware to set the standard. We believe that the likely proliferation of forum-selection bylaws will enhance Delaware's ability to do so. We note, however, that our proposal is available to other states and, indeed, that the state of Texas has adopted an approach that is analogous to what we suggest, albeit not focused specifically on the context of merger litigation. ${ }^{269}$

Perhaps the most straightforward approach for eliminating fee awards in disclosure-only settlements would be for courts to stop recognizing disclosure-only settlements as producing a shareholder benefit sufficient to entitle plaintiffs' lawyers to a fee award. Because the corporate benefit doctrine is a judicially created doctrine, ${ }^{270}$ courts could implement this change themselves. We note that some Delaware judges seem to be moving in this direction on a case-specific basis. However, we recognize that judges are accustomed to applying discretion on a case-by-case basis and generally prefer rules that preserve rather than restrict their discretion. As a

265. See supra notes $189-94$ and accompanying text.

266. See supra notes $189-94$ and accompanying text.

267. See supra notes $189-94$ and accompanying text.

268. See, e.g., Michael Klausner et al., When Are Securities Class Actions Dismissed, When Do They Settle, and for How Much? - An Update, PLUS J., Apr. 2013, at 1, 8 (reporting, based on a study of all securities class actions filed between 2006 and 2010 , that " $38 \%$ of cases ended relatively quickly and painlessly for the defendants").

269. See infra notes $272-76$ and accompanying text.

270. See supra notes $97-100$ and accompanying text. 
result, the courts may be unwilling to adopt a per se rule that binds their own hands. ${ }^{271}$

An alternative would be for the courts, again as a matter of common law, to cut back on the breadth of the substantive duty of disclosure. As we noted earlier, the Delaware duty of disclosure is of relatively recent origin, arguably broader than the federal law course of action, and somewhat imperfectly articulated because of the procedural context in which it is most frequently applied. We suspect that the emergence of the duty of disclosure and the articulation by several courts of broad disclosure obligations, particularly with respect to the work and incentives of investment bankers in connection with control transactions, has contributed to the proliferation of merger litigation, especially because, under the existing obligation, disclosure challenges cannot readily be resolved on a motion to dismiss. A substantive change to Delaware fiduciary duty law is a more ambitious response than our proposal requires, but it would be an effective solution as well. Notably, a modification to the substantive duty of disclosure would reduce the ability of plaintiffs to evade the change through forum shopping.

A third option would be for the Delaware legislature to adopt our proposed solution. The most straightforward mechanism would be a statute that bars the award of attorneys' fees in disclosure-only settlements of merger litigation. As an example of such an action, the Texas Legislature recently instructed the Texas Supreme Court to amend the rules of civil procedure to prohibit the award of cash attorneys' fees in class actions that are settled for coupons or other nonpecuniary benefits, a rule that goes farther than our own proposal. ${ }^{272} \mathrm{~A}$ recent decision of the Texas Court of Appeals, Kazman, ${ }^{273}$ held that this provision precluded the trial court from awarding monetary fees to class counsel in connection with a proposed disclosure-only merger settlement. ${ }^{274}$

An important distinction between the Texas provision and our proposal is that the Texas legislation is not confined to merger cases. ${ }^{275}$ The motivation for the Texas law was a concern about coupon settlements in

271. On the other hand, members of the Chancery Court might be relieved not to have to wade into the morass of fee disputes for what is now a large category of cases. See Daniel Fisher, Delaware Judge Strine: 'I'm Not Going to Give Big Fees for Junk,' FORBES (Oct. 24, 2012, 3:10 PM), http://www.forbes.com/sites/danielfisher/2012/10/24/delaware-judge-strine-im-notgoing-to-give-big-fees-for-junk/, archived at http://perma.cc/F3KQ-P739 (quoting Chancellor Strine as stating "I'm not going to give big fees for junk" and that "[w] hat does trouble me is the hundreds and hundreds of lawsuits where the only beneficiary is the trial lawyer").

272. Act of June 11, 2003, 78th Leg., R.S., ch. 204, § 1.01, secs. 26.001-.002, 2003 Tex. Gen. Laws 847, 847-48 (codified at Tex. Civ. Prac. \& Rem. Code Ann. $\S \S 26.001-.003$ (West 2014)).

273. Kazman v. Frontier Oil Corp., 398 S.W.3d 377 (Tex. App.--Houston [14th Dist.] 2013, no pet.).

274. Id. at 387.

275. TeX. Civ. PRAC. \& REM. CODE ANN. §§ 26.001-.003 (West 2014). 
class litigation generally. ${ }^{276}$ This concern has been raised in other substantive contexts such as consumer and antitrust class actions. ${ }^{277}$ Yet from a political-economy perspective, enacting merger-specific legislation is a logical approach for Delaware given its interests in protecting target corporations incorporated within the state from unfounded and excessive litigation challenges. ${ }^{278}$ Delaware also benefits by removing unnecessary obstacles to the merger of Delaware corporations because such an action increases the expected value of corporations incorporated in the state. ${ }^{279}$

A deeper question occasioned by our proposal is whether Delaware will willingly cede some of the authority it now possesses in merger regulation to federal courts. Our proposal would have the effect of making federal courts, rather than Delaware, the central authority for evaluating the quality of disclosures in public company mergers. ${ }^{280}$ Ceding this role would go against the state's seeming incentive to maximize its authority over businesses incorporated within the state. ${ }^{281}$ We argue that our empirical findings provide convincing evidence that the power conferred on the Delaware courts by ubiquitous and weak merger litigation challenges is illusory. The cases resolved through disclosure-only settlements do not

276. See Michael Northrup, Restrictions on Class-Action Attorney-Fee Awards, 46 S. TEX. L. REV. 953, 961 (2005) ("The adoption of the coupon rule evidences the legislature's dissatisfaction with the practice of leveraging the class-action device into settlements that provide insignificant recoveries (or effectively no recovery) to class members, while the class attorneys recover large cash awards.").

277. James Tharin \& Brian Blockovich, Coupons and the Class Action Fairness Act, 18 GEO. J. LEGAL ETHICS 1443, 1445-47 (2005); see also 28 U.S.C. $\$ 1172$ (d) (2012) (barring coupon settlements without court approval).

278. See Roberta Romano, The Genius of American Corporate LAW 8-9 (1993) (describing political-economy reasons for the Delaware legislature's responsiveness to corporate interests). Delaware derived $\$ 534,236,586$ in revenue in 2008 from fees paid by corporations and other business associations. Mark J. Roe, Delaware's Shrinking Half-Life, 62 STAN. L. REV. 125, 136 tbl.3 (2009).

279. See Robert Daines, Does Delaware Law Improve Firm Value?, 62 J. Fin. ECON. 525, 527-28 (2001) (hypothesizing that the value of Delaware firms reflect, in part, their amenability to a takeover under a balanced regulatory regime).

280. This would encompass a reallocation of authority to the federal government after a long period of acquiescence. Steven M. Davidoff, The SEC and the Failure of Federal Takeover Regulation, 34 FLA. ST. U. L. REV. 211, 269 (2007).

281. See Steven M. Davidoff, A Case Study: Air Products v. Airgas and the Value of Strategic Judicial Decision-Making, 2012 COLUM. BUS. L. REV. 502, 505-06 (2012) (positing that Airgas provides insight into how Delaware courts seek to maximize Delaware's dominance); Sean J. Griffith, Good Faith Business Judgment: A Theory of Rhetoric in Corporate Law Jurisprudence, 55 DUKE L.J. 1, 55 (2005) (recognizing the direct threat, imposed by the possibility of corporate migration, to Delaware's revenue as a likely reason for the legislature's responsiveness to corporate suggestion); Marcel Kahan \& Edward Rock, How to Prevent Hard Cases from Making Bad Law: Bear Stearns, Delaware and the Strategic Use of Comity, 58 EMORY L.J. 713, 714-15 (2009) (noting Delaware's immense financial success as a result of its control of corporate lawmaking). 
provide the Delaware courts with a meaningful role in implementing merger standards. Freeing the courts from these cases would empower the courts to do what they do best-deciding real cases and setting substantive and procedural standards that matter from the perspective of business practices and shareholder value.

\section{Conclusion}

We have examined the value of nonpecuniary relief in merger litigation from a heretofore neglected angle-its effect on shareholder voting. We find that amendment settlements have some demonstrable effect on shareholder voting but that disclosure-only settlements do not. The clear implication of these findings is that disclosure-only settlements do not produce a corporate benefit.

Because disclosure-only settlements produce costs but no benefits, we argue that they should be eliminated. An easy way to accomplish this is removing the judicially created incentive for plaintiffs' attorneys to bring these cases by rejecting the claim that a disclosure-only settlement is a corporate benefit for purposes of Delaware law. This approach would not leave shareholders without recourse if merger disclosures are materially deficient; instead they would be required to litigate true disclosure claims under the federal securities laws, preserving state merger litigation for challenges to the substantive and procedural fairness of the merger terms. The effect of adopting this policy would be to eliminate much wasteful litigation while still preserving the ability of Delaware courts to decide more substantial challenges to deals. 


\section{Appendix}

\section{Table III (All Variables)}

Table III reports ordinary least squares regressions in which the dependent variable in columns (1) and (2) is \% Yes Votes Per Votes Cast; columns (3) and (4) is \% Yes Votes Per Outstanding Shares; and columns (5) and (6) are\% Yes Votes Per All Yes \& No Votes. \% Yes Votes Per Votes Cast is the percentage of yes votes out of all votes cast at the meeting, including abstentions. \% Yes Votes Per Outstanding Shares is the percentage of yes votes out of the total outstanding voting shares of the target and eligible to vote as of the record date for the meeting. \% Yes Votes Per All Yes \& No Votes is the percentage of yes votes out of the total number of yes and no votes cast at the meeting. The sample is as described in subpart II(A), infra. Initial Offer Premium is the initial offer price over target's trading price thirty days prior to merger announcement. Final Offer Premium is the final price paid over target's trading price thirty days prior to announcement. Cash indicates the consideration paid is all cash, Auction indicates the transaction is initiated as an auction among multiple bidders instead of a privately-negotiated sale, Go shop indicates that the merger agreement includes a provision that allows the target company to actively solicit other potential bidders for a specific limited period of time after the merger agreement has been signed, Take Private indicates that a Schedule $13 \mathrm{E}-3$ has been filed with the SEC for the transaction due to the buyer being an affiliated party. ISS Position $=0$ means ISS recommended that its' client shareholders do not vote or vote against the transactions. ISS Position $=1$ means that ISS recommended that its client shareholders vote for the transaction. Appraisal Exercise $=1$ if any shareholder exercised appraisal rights and $=0$ otherwise. Disclosure Settlement requires the target to make an additional disclosure concerning the transaction; ConsiderationIncrease Settlement provides for an increase in the consideration payable to target shareholders; and Amendment Settlement requires the terms of the transaction to be revised. Amendment Settlement also includes settlements that have as a component a Disclosure Settlement. Consideration-Increase Settlement also includes settlements that have as a component Amendment or Disclosure Settlements. Supermajority State $=1$ if the state of incorporation of the target requires greater than $50 \%$ of shareholders to approve a merger and $=0$ otherwise. $P$-values are in parentheses, with $* * *$, $* *$, and ${ }^{*}$ denoting statistical significance at the $1 \%, 5 \%$, and $10 \%$ levels, respectively. The models in columns (1), (3), and (5) include only targets incorporated in Delaware and where the acquisition is all cash. All models include year-fixed effects. $P$-values are in parentheses, with ${ }^{* * *},{ }^{* *}$, and $*$ denoting statistical significance at the $1 \%, 5 \%$, and $10 \%$ levels, respectively. 


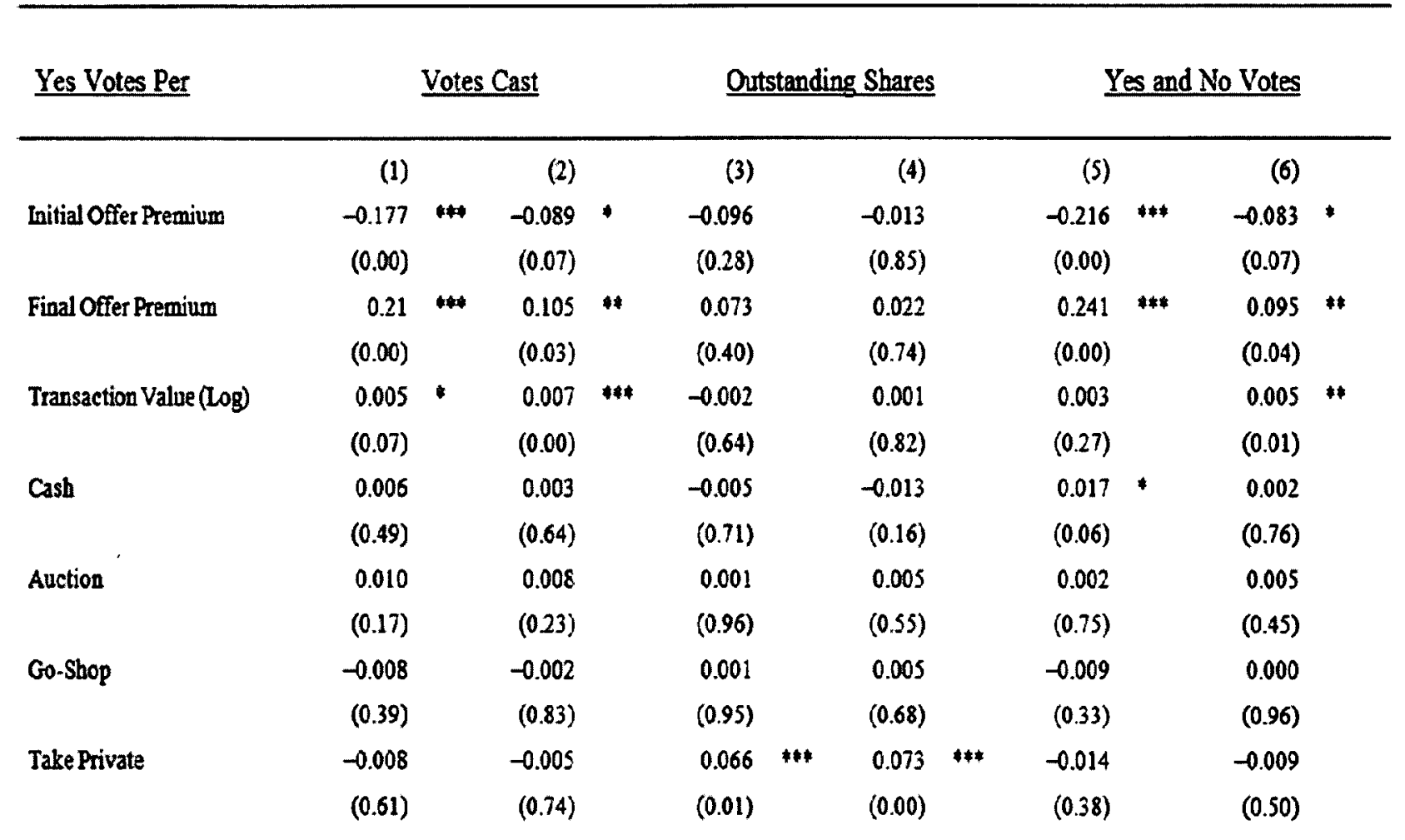




\begin{tabular}{|c|c|c|c|c|c|c|c|c|c|c|c|c|}
\hline \multirow[t]{2}{*}{ Yes Votes Per } & \multicolumn{4}{|c|}{ Votes Cast } & \multicolumn{4}{|c|}{ Outstanding Shares } & \multicolumn{4}{|c|}{ Yes and No Votes } \\
\hline & (1) & & (2) & & (3) & & (4) & & (5) & & (6) & \\
\hline \multirow[t]{2}{*}{ ISS Position } & 0.231 & $\$$ ** & 0.155 & $4 * *$ & 0.153 & *** & 0.113 & $* *$ & 0.184 & $\Leftrightarrow * *$ & 0.124 & $* * 4$ \\
\hline & $(0.00)$ & & $(0.00)$ & & $(0.00)$ & & $(0.00)$ & & $(0.00)$ & & $(0.00)$ & \\
\hline \multirow[t]{2}{*}{ Appraisal Exercise } & 0.033 & ** & & & 0.030 & & & & 0.020 & & & \\
\hline & $(0.05)$ & & & & $(0.22)$ & & & & $(0.16)$ & & & \\
\hline \multirow[t]{2}{*}{ Disclosure Settlement } & 0.008 & & 0.000 & & 0.023 & $*$ & 0.011 & & 0.009 & & 0.003 & \\
\hline & $(0.31)$ & & $(0.98)$ & & $(0.06)$ & & $(0.22)$ & & $(0.20)$ & & $(0.58)$ & \\
\hline \multirow[t]{2}{*}{ Amendment Settlement } & 0.018 & & 0.008 & & 0.068 & $* * *$ & 0.045 & $* *$ & 0.03 & $*$ & 0.017 & \\
\hline & $(0.13)$ & & $(0.51)$ & & $(0.00)$ & & $(0.01)$ & & $(0.01)$ & & $(0.12)$ & \\
\hline \multirow[t]{2}{*}{$\begin{array}{l}\text { Consideration Increase } \\
\text { Settlement }\end{array}$} & 0.036 & $*$ & 0.005 & & 0.100 & $* * *$ & 0.057 & $\omega$ & 0.025 & & 0.004 & \\
\hline & $(0.07)$ & & $(0.80)$ & & $(0.00)$ & & $(0.022)$ & & $(0.15)$ & & $(0.809)$ & \\
\hline \multirow[t]{2}{*}{ Supermajority State } & & & -0.015 & \$* & & & 0.014 & & & & -0.010 & \\
\hline & & & $(0.05)$ & & & & $(0.17)$ & & & & $(0.19)$ & \\
\hline Observations & 215 & & 391 & & 237 & & 423 & & 168 & & 293 & \\
\hline$R$-squared & 0.5007 & & 0.2658 & & 0.21 & & 0.1228 & & 0.4401 & & 02252 & \\
\hline
\end{tabular}




\section{Table IV (All Variables)}

Table IV reports ordinary least squares regressions in which the dependent variable in columns (1) \& (2) is \% Yes Votes Per Votes Cast; columns (3) and (4) is \% Yes Votes Per Outstanding Shares; and columns (5) and (6) are \% Yes Votes Per All Yes \& No Votes. \% Yes Votes Per Votes Cast is the percentage of yes votes out of all votes cast at the meeting, including abstentions. Attorneys Fee $>500$ is coded $=1$ if the attorneys' fees awarded in the litigation are greater than $\$ 500,000$ and $=0$ if the attorneys' fees awarded are less than $\$ 500,000$. Attorney Fees (Log) is the $\log$ value of the attorneys' fees awarded in the settlement. All other variables are as defined in Table III(A). All models include year-fixed effects. $P$-values are in parentheses, with ${ }^{* * *}, * *$, and ${ }^{*}$ denoting statistical significance at the $1 \%, 5 \%$, and $10 \%$ levels, respectively. 


\begin{tabular}{|c|c|c|c|c|c|c|c|c|c|c|c|c|}
\hline \multirow{3}{*}{$\begin{array}{l}\text { Yes Votes Per } \\
\text { Initial Offer Premium }\end{array}$} & \multicolumn{3}{|c|}{ Votes Cast } & & \multicolumn{4}{|c|}{ Outstanding Shares } & \multicolumn{4}{|c|}{ Yes and No Votes } \\
\hline & \multicolumn{2}{|l|}{ (1) } & \multicolumn{2}{|l|}{ (2) } & \multicolumn{2}{|l|}{ (3) } & \multicolumn{2}{|l|}{ (4) } & \multicolumn{2}{|l|}{ (5) } & \multicolumn{2}{|l|}{ (6) } \\
\hline & -0.456 & $* * *$ & -0.170 & $* * *$ & -0.337 & $* *$ & -0.107 & & -0.413 & $* *$ & -0.175 & $* * *$ \\
\hline & $(0.00)$ & & $(0.00)$ & & $(0.03)$ & & $(0.26)$ & & $(0.00)$ & & $(0.00)$ & \\
\hline \multirow[t]{2}{*}{ Final Offer Premium } & 0.479 & $* *$ & 0.172 & $\ldots$ & 0.294 & - & 0.08 & & 0.436 & $\cdots$ & 0.18 & 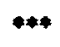 \\
\hline & $(0.00)$ & & $(0.00)$ & & $(0.06)$ & & -0.374 & & $(0.00)$ & & $-1 E-04$ & \\
\hline \multirow[t]{2}{*}{ Transaction Value (Log) } & 0.008 & $*$ & 0.009 & $* *$ & -0.012 & $*$ & -0.006 & & 0.008 & $* *$ & 0.007 & ** \\
\hline & $(0.01)$ & & $(0.00)$ & & $(0.07)$ & & $(0.23)$ & & $(0.04)$ & & $(0.02)$ & \\
\hline \multirow[t]{2}{*}{ Cash } & 0.005 & & 0.010 & & -0.006 & & -0.015 & & 0.014 & & 0.007 & \\
\hline & $(0.62)$ & & $(0.29)$ & & $(0.78)$ & & -0.336 & & $(0.20)$ & & -0.438 & \\
\hline \multirow[t]{2}{*}{ Auction } & 0.012 & & 0.005 & & 0.006 & & 0.009 & & 0.008 & & 0.008 & \\
\hline & $(0.15)$ & & $(0.51)$ & & $(0.72)$ & & $(0.47)$ & & $(0.42)$ & & $(0.31)$ & \\
\hline \multirow[t]{2}{*}{ Go-Shop } & -0.019 & $*$ & -0.004 & & 0.015 & & 0.012 & & -0.010 & & 0.004 & \\
\hline & $(0.06)$ & & $(0.70)$ & & $(0.44)$ & & $(0.44)$ & & $(0.37)$ & & $(0.71)$ & \\
\hline \multirow[t]{2}{*}{ Take Private } & -0.014 & & -0.01 & & 0.079 & $*$ & 0.076 & $* * *$ & -0.016 & & -0.015 & \\
\hline & $(0.42)$ & & $(0.54)$ & & $(0.02)$ & & $(0.00)$ & & $(0.41)$ & & $(0.39)$ & \\
\hline \multirow[t]{2}{*}{ ISS Position } & 0.216 & $* * *$ & 0.195 & $* * *$ & 0.223 & $* * *$ & 0.14 & $* * *$ & 0.201 & $* * *$ & 0.169 & $* * *$ \\
\hline & $(0.00)$ & & $(0.00)$ & & $(0.00)$ & & $(0.00)$ & & $(0.00)$ & & $(0.00)$ & \\
\hline
\end{tabular}




\begin{tabular}{|c|c|c|c|c|c|c|c|c|c|c|c|}
\hline \multirow[t]{2}{*}{ Attomey Fee $>500$} & -0.001 & & 0.006 & & -0.01 & & 0.01 & -0.006 & & -0.003 & \\
\hline & $(0.95)$ & & $(0.54)$ & & $(0.62)$ & & $(0.52)$ & $(0.55)$ & & $(0.74)$ & \\
\hline \multirow[t]{2}{*}{ Aftomey Fees (Log) } & -0.009 & * & -0.013 & $*$ & 0.002 & & -0.005 & -0.007 & & -0.005 & \\
\hline & $(0.09)$ & & $(0.03)$ & & $(0.86)$ & & $(0.57)$ & $(0.25)$ & & $(0.36)$ & \\
\hline \multirow[t]{2}{*}{ Appraisal Exercise } & 0.012 & & & & 0.026 & & & -0.002 & & & \\
\hline & $(0.47)$ & & & & $(0.40)$ & & & $(0.89)$ & & & \\
\hline \multirow[t]{2}{*}{ Disclosure Settlement } & 0.009 & & 0.006 & & 0.000 & & -0.010 & 0.017 & & 0.016 & \\
\hline & $(0.45)$ & & $(0.67)$ & & $(1.00)$ & & $(0.64)$ & $(0.19)$ & & $(0.21)$ & \\
\hline \multirow[t]{2}{*}{ Amendment Settlement } & 0.03 & $*$ & 0.027 & - & 0.054 & * & 0.029 & 0.037 & $*$ & 0.034 & $*$ \\
\hline & $(0.05)$ & & $(0.09)$ & & $(0.09)$ & & $(0.27)$ & $(0.02)$ & & $(0.03)$ & \\
\hline \multirow{3}{*}{$\begin{array}{l}\text { Consideration lncrease } \\
\text { Settlement }\end{array}$} & & & & & & & & & & & \\
\hline & 0.054 & $* *$ & 0.035 & & 0.08 & ** & 0.046 & 0.047 & ** & 0.024 & \\
\hline & $(0.01)$ & & $(0.11)$ & & $(0.05)$ & & $(0.19)$ & $(0.03)$ & & $(0.23)$ & \\
\hline \multirow[t]{2}{*}{ Supermajority State } & & & -0.037 & $* * *$ & & & 0.006 & & & -0.024 & $"$ \\
\hline & & & $(0.00)$ & & & & $(0.72)$ & & & $(0.03)$ & \\
\hline Observations & 109 & & 175 & & 118 & & 190 & 93 & & 144 & \\
\hline R-squared & 0.6473 & & 0.4259 & & 0.318 & & 0.1558 & 0.5527 & & 0.335 & \\
\hline
\end{tabular}




\section{Table V (All Variables)}

Table $\mathrm{V}$ reports ordinary least squares regressions in which the dependent variable in columns (1) \& (2) is \% Yes Votes Per Votes Cast; columns (3) and (4) is \% Yes Votes Per Outstanding Shares; and columns (5) \& (6) are \% Yes Votes Per All Yes \& No Votes. \% Yes Votes Per Votes Cast is the percentage of yes votes out of all votes cast at the meeting, including abstentions. Columns (1)-(4) include all transactions in the sample, and columns (5) and (6) include only mergers with a transaction value less than $\$ 500$ million. Institutional Ownership \% is the percentage of total institutional ownership. Top 5 Institutional Ownership is the percentage ownership of the largest five institutional owners. Top 10 Institutional Ownership is the percentage ownership of the largest ten institutional owners. Maximum Institutional Ownership is the percentage ownership of the largest institutional owner. Institutional ownership for each of these variables is as of the quarter end immediately prior to the shareholder meeting date. All other variables are as defined in Table III(A). All models include year-fixed effects. $P$-values are in parentheses, with $* * *, * *$, and $*$ denoting statistical significance at the $1 \%, 5 \%$, and $10 \%$ levels, respectively. 


\begin{tabular}{|c|c|c|c|c|c|c|c|c|c|c|}
\hline \multicolumn{11}{|c|}{ Shareholder Yes Votes Per Votes Cast } \\
\hline & \multicolumn{6}{|c|}{ All Transactions } & \multicolumn{4}{|c|}{$\frac{\text { Transaction Value }}{\leq 5500 \mathrm{M}}$} \\
\hline & (1) & & (2) & (3) & & (4) & & (5) & (6) & \\
\hline \multirow[t]{2}{*}{ Institutional Ownership $\%$} & 0.041 & $*$ & 0.033 & 0.023 & & 0.008 & & 0.062 & -0.043 & \\
\hline & $(0.01)$ & & $(0.41)$ & $(0.52)$ & & $(0.89)$ & & $(0.14)$ & $(0.74)$ & \\
\hline \multirow[t]{2}{*}{ Initial Offer Premium } & -0.062 & & -0.062 & -0.098 & $* *$ & -0.151 & ** & -0.158 & -0.173 & ** \\
\hline & $(0.24)$ & & $(0.25)$ & $(0.04)$ & & $(0.04)$ & & $(0.11)$ & $(0.04)$ & \\
\hline \multirow[t]{2}{*}{ Final Offer Premium } & 0.086 & & 0.085 & 0.113 & $* *$ & 0.186 & *** & 0.175 & 0.182 & ** \\
\hline & $(0.10)$ & & $(0.11)$ & $(0.02)$ & & $(0.01)$ & & $(0.07)$ & $(0.03)$ & \\
\hline \multirow[t]{2}{*}{ Transaction Value (Log) } & 0.004 & $*$ & 0.004 & 0.004 & & 0.007 & & -0.034 & -0.001 & \\
\hline & $(0.10)$ & & $(0.19)$ & $(0.14)$ & & $(0.20)$ & & $(0.07)$ & $(0.94)$ & \\
\hline \multirow[t]{2}{*}{ Top 5 Institutional Ownership } & & & -0.124 & -0.108 & & -0.128 & & & 0.086 & \\
\hline & & & $(0.55)$ & $(0.56)$ & & $(0.65)$ & & & $(0.84)$ & \\
\hline \multirow[t]{2}{*}{ Top 10 Institutional Ownership } & & & 0.085 & 0.086 & & 0.151 & & & 0.141 & \\
\hline & & & $(0.62)$ & $(0.58)$ & & $(0.53)$ & & & $(0.74)$ & \\
\hline \multirow[t]{2}{*}{ Maximum Institutional Ownership } & & & 0.056 & 0.031 & & 0.031 & & & -0.191 & \\
\hline & & & $(0.64)$ & $(0.78)$ & & $(0.83)$ & & & $(0.44)$ & \\
\hline
\end{tabular}




\begin{tabular}{|c|c|c|c|c|c|c|c|}
\hline \multicolumn{8}{|c|}{ Shareholder Yes Votes Per Votes Cast } \\
\hline & \multirow{2}{*}{\multicolumn{4}{|c|}{ All Transactions }} & \multirow{2}{*}{\multicolumn{3}{|c|}{$\frac{\text { Transaction Value }}{\leq \$ 500 \mathrm{M}}$}} \\
\hline & & & & & & & \\
\hline & (1) & (2) & (3) & (4) & $(5)$ & (6) & \\
\hline \multirow{2}{*}{ ISS Position } & & & 0.154 & $* *$ & & 0.232 & $* *$ \\
\hline & & & $(0.00)$ & & & $(0.00)$ & \\
\hline \multirow[t]{2}{*}{ Disclosure Settlement } & & & 0.00 & 0.01 & & -0.021 & \\
\hline & & & $(0.68)$ & $(0.48)$ & & $(0.19)$ & \\
\hline \multirow[t]{2}{*}{ Amendment Settlement } & & & 0.01 & 0.01 & & -0.035 & \\
\hline & & & $(0.47)$ & $(0.67)$ & & $(0.31)$ & \\
\hline \multirow[t]{2}{*}{ Consideration Increase Settlement } & & & 0.00 & -0.03 & & 0.025 & \\
\hline & & & $(0.91)$ & $(0.20)$ & & $(0.75)$ & \\
\hline \multirow[t]{2}{*}{ Appraisal Exercise } & & & & -0.01 & & & \\
\hline & & & & $(0.68)$ & & & \\
\hline Observations & 393 & 393 & 391 & 216 & 140 & 140 & \\
\hline$R$-squared & 0.0543 & 0.055 & 0.2642 & 0.0897 & 0.063 & 0.3439 & \\
\hline
\end{tabular}

